\title{
O commercio maritimo e o navio
}

\author{
I \\ O COMMERCIO MARITIMO
}

1. - O COMMERCIO MARITIMO - Como o livro segundo do codigo commercial francez, trata a segunda parte do brasileiro do commercio maritimo, que lhe serve de titulo. Ha, nisso, evidentemente, como salienta Alber r WAHL, um vicio de methodo, que a distribuição das materias manifesta (1), justificavel se o livro primeiro daquelle, como a primeira parte deste, em vez de ter por objecto o commercio em geral, só do terrestre cogitasse.

No intuito de evitar a interpretação de que, em taes termos, não se comprehenderia no commercio maritimo nem o fluvial, nem o lacustre, alguns codigos, como o hollandez e o italiano, ajuntaram á denominação as expressões - e da navegação, "del commercio marittimo e della navigazione”, qual neste ultimo se lê.

(1) Albert Wahl, Précis Theorique et Pratique de Droit Maritime, pag. $3, \mathrm{n}^{\circ} 1$. 
Mais apropriadamente, tem o livro terceiro do codigo argentino, bem assim o do uruguayo, por objecto os direitos e obrigações resultantes da navegação. Isso levou LISandro Segovia a observar que de sua epigraphe: "de los derechos y obligaciones que resultan de la navegacion" (2), deduz-se occupar-se elle da navegação em geral e não do commercio maritimo ou de mar. As suas disposições não fazem differença entre o commercio maritimo e o fluvial ou o de cabotagem. Applicam-se a todas as especies de navegação.

2. - A INDUSTRIA DA NEVEGAÇÃO - Preferiu, por isso, Inglez de Souza dar ao livro quarto do seu projecto de codigo commercial por conteudo e titulo - industria de navegação, "não só por ser mais comprehensiva do que a geralmente usada, como porque ao mesmo tempo restringe o campo da legislação ás relações de direito privado, afastando qualquer confusão com o direito maritimo internacional e com o direito publico administrativo que rege as relações maritimas ou fluviaes entre os poderes publicos do Estado e entre estes e os particulares, e cuja regulação pertence ás leis e regulamentos da marinha mercante" (3).

Não viu Rodrigo Octavio razão de ordem technica, em favor de tal mudança; pois "a expressão commercio maritimo está consagrada pelo uso, indica approximadamente o objecto definido, sem gerar confusões com o direito maritimo internacional, onde não ha relações de ordem commercial, nem com o aspecto administrativo da navegação, apreciado nos regulamentos de cabotagem, marinha mercante e capitanias de portos"

$\mathrm{E}$, salientando que "a expressão commercio bem especializa quaes sejam as relações da actividade maritima a que se refere essa parte do codigo", accrescentou:

(2) Lisandro Segovia, Explicacion y Critica del Nuevo Código de Comercio de la Republica Argentina, vol. 2, pag. 340, n. 2.822.

(3) H. M. Inglez de SouzA, Projecto de Codigo Commercial. vol. 1, Introducção, pag. 78. 
“Didacticamente, o que havia a ponderar era quanto á regularidade da inclusão de principios de direito maritimo num codigo de direito commercial.

Além de que naquelle corpo de principios se compendiam regras referentes a institutos de natureza civil, como todas as relativas á individuação do navio (nome, capacidade, domicilio) propriedade, meios de acquisição e alienação, hypotheca, seguros, abalroação, assistencia, salvamentos de pessôas e de cousas, é notorio que o direito maritimo se rege, na generalidade dos seus institutos, mesmo em alguns que têm natureza mercantil, por nórmas proprias, diversas, quando não caracteristicamente divergentes, das nórmas geraes de direito" (4).

3. - O COMMERCIO NAUTICO - Reconhecendo menos correcta a denominação de commercio maritimo - o que se faz mediante ou a proposito do transporte por agua, por meio da navegação, preferiu Brasillo Machado chamal-o de commercio nautico. Remontou á technica do direito romano. Este, se não distinguir, nitidamente, o direito commercial terrestre do civil, delle perfeitamente discriminava o maritimo, ou nautico. No Codigo, liv. IV, lit. 33, e no Digesto, liv. XXII, tit. 2, esta denominação apparece: de nautico foenore (5).

A impropriedade da denominação da segunda parte do codigo commercial mais se patenteia, quando se considera que o commercio, interno ou externo, entre duas praças pelo mar separadas, é sempre o mesmo: em terra inicia-se, ajusta-se em terra e em terra é executado. O navio funcciona, simplesmente, como meio de transporte. Celebrados por via de correspondencia epistolar, telegraphica ou radiographica, os contractos, entretanto, não mudam de natureza: conti-

(4) Revista Juridica, vol. 6, de 1917, pag. 407, e vol. 17, de 1920, pag. 168 .

(5) Brasilio Machado, Prelecções de Direito Commercial, tachygraphadas por Augusto Moreira Soares, S. Paulo, 1906, pag. 135. 
nuam disciplinados pelas mesmas normas de direito privado, commerciaes ou civis.

4. - O CONTEUDO DO COMMERCIO MARITIMO Tem o commercio maritimo, não obstante, conteudo proprio. Actos e contractos especialissimos o entretecem: a construcção do navio, modos de acquisição da sua propriedade, a sua armação, locação de serviços, corretagens, a sua fretação, riscos.

Bem movel, parte de um patrimonio, serve de garantia ou de lastro para innumeros contractos e é susceptivel de hypotheca, ainda que em construcção; instrumento de transporte, delle se originam e sobre elle recaem direitos e obrigações que formam o systema do direito maritimo.

5 - A LIBERDADE DO COMMERCIO MARITIMO - 0 commercio maritimo é livre: podem pratical-o os habitantes de todos os paizes. Devem os Estados, que fazem partes da communhão internacional, abrir os seus portos ao commercio extrangeiro, permittindo nelles ancorem todos os navios e no seu territorio penetrem os extrangeiros e ahi se domiciliem e exerçam a sua actividade, sob a protecção das leis. Essa liberdade de commercio e franqueamento de portos, todavia, não lhes pode impedir a tomada de medidas de policia, vigiando as suas fronteiras, fiscalizando a importação e a exportação e praticando todas as providencias acauteladoras dos superiores interesses da collectividade. Isso, como é de ver, no exercicio da sua soberania. Mas até onde vae esta?

Em tempo de paz, como no de guerra, o alto mar é navegavel pelos navios de todos os povos: elle constitue, no dizer do Conselheiro Lafayette, uma especie de servidão commum a todos os povos, para todo o genero de communicações e transportes. Têm, por isso, todas as nações o direito de navegação, isto é, de fazer transportar pessôas e cousas, pelo mar alto, por navios seus, para quaesquer e de quaesquer pontos. Cada navio, ahi, e isso é corrente em direito 
internacional, conserva-se sob a soberania e sob a protecção do Estado a que pertence. Desses principios resulta:

a) que, em tempo de paz, não póde um Estado embaraçar ou impedir a viagem do navio de outra nação, nem dar-lhe ordens, nem sujeital-o a visita ou pesquiza de qualquer natureza;

b) que são regidos pelas leis da nação do navio todos os actos, civis ou criminaes, occorridos a bordo;

c) que só as autoridades, juizes e tribunaes da nação do navio têm competencia exclusiva para tomar conhecimento desses actos, julgal-os e deliberar a respeito (6).

$\mathrm{O}$ alto mar, portanto, não é de ninguem: é de todos, mercê de uma communhão negativa de todas as nações. A nenhuma é licito apropriar-se delle ou sobre elle exercer jurisdicção.

Não foi, porém, sempre assim.

"O direito romano", é de uma pagina de Clovis BevilaQUA, "o direito romano punha o mar fóra do commercio: mari, quod natura omnibus patet, servitus imponi privata lege non potest, mas, nas relações internacionaes, assim não era, porque a tendencia de Roma foi assenhorear-se do mundo, e os imperadores romanos se consideravam senhores da terra, mundi domini. Na edade media e nos inicios da edade moderna, os diversos Estados maritimos pretendiam o dominio dos mares. Veneza julgava-se com direito ao mar Adriatico, Portugal ao de Guiné, Hespanha ao oceano Pacifico, a Inglaterra aos mares que banham as ilhas britannicas" (7).

Nos dias actuaes, e depois de vencedora a doutrina do mare liberum, primeiro defendida por Grocio, o principio da liberdade dos mares está, definitivamente, consagrado.

(6) Lafayette Rodrigues Pereira, Principios de Direito Internacional, vol. 1, pags. 176 e 172, $\S 106$ e 111.

(7) Chovis Bevilaqua, Direito Publico Internacional, vol. 2, pag. $74, \S 199, \mathrm{I}$. 
Mas que se deve entender por mar alto ou mar livre? Pois não está o oceano dividido em mar livre ou mar alto e em mar adjacente, ou mar costeiro, ou mar litoral, ou mar territorial? Se sim, onde acaba o mar territorial? Onde começa o mar alto? E' possivel determinar a linha de separação delles?

6. - O MAR LIVRE E O MAR TERRITORIAL - Fazem parte do territorio das nações por uma ficção de direito os mares que lhes banham as costas. Preceitua o art. 1 da introducção do codigo civil ser a lei obrigatoria em todo o territorio brasileiro, nas suas aguas territoriaes e, ainda, no estrangeiro, até onde lhe reconhecerem exterritorialidade os principios e convenções internacionaes; e o art. 4 do codigo penal inclue na definição de territorio brasileiro, além dos navios brasileiros em alto mar, dos navios mercantes estrangeiros surtos em porto brasileiro, dos navios de guerra nacionaes em porto estrangeiro, os portos e os mares territoriaes.

Existe, effectivamente, uma linha, parallela á costa, separando o mar territorial do mar alto, uma linha de respeito, limite da jurisdicção do Estado sobre a parte de mar ao seu territorio adjacente. Para os povos antigos, como os phenicios, essa linha era a da baixa mar, o limite minimo a que chegam as marés; e a da preamar, o limite maximo a que ellas chegam, para os gregos.

Varios systemas, entretanto, foram propostos para essa fixação de zonas maritimas. Punha Loccenıus a linha de respeito no logar que um navio alcançasse após dois dias de viagem. Fundava-a Valin na profundidade do mar. Confundia-a Gerard de Rayneval com o horizonte real, o ponto mais distante ao olho do observador, collocado na praia. Bem comprehendendo ser mar territorial o em que os Estados podem exercer os seus actos de soberania, e a inexistencia desta sem a força necessaria para dar-lhe efficacia, viu-o Grocio na extensão do mar possivel de ser coberta por um tiro de canhão collocado na praia. Eis a douîrina vencedora em direito internacional - a do Alvará 
de 4 de maio de 1805. Mandava se considerassem "mares territoriaes e adjacentes, em tanta distancia, quanta abranger o tiro de canhão, ainda que não haja bateria em frente, porque a sua existencia se presume para este unico caso de reciproca immunidade"

Vingou o pensamento de Bynkershoek: terrae dominium finitur, ubi finitur armorum vis, sem embargo de não estar esse principio consagrado numa formula precisa e segura. O Instituto de Direito Internacional, em sua sessão de Paris, em 1894, extendeu o mar territorial até seis milhas maritimas (de 60 por gráo), contadas da praia na vasante, ao longo das costas. Em caso de guerra, o ribeirinho neutro tem o direito de fixar, na sua declaração de neutralidade ou por notificação especial, sua zona neutra, além de seis milhas, até onde alcançam os canhões da costa.

A soberania do Estado sobre o seu mar territorial é completa, absoluta. Por costume e pratica geral, não lhe é licito impedir, em suas aguas, a navegação innocente, o transito innoxio dos navios mercantes e vasos de guerra das nações estrangeiras. Póde elle, no emtanto, exercel-a:

a) pela policia de segurança, destinada á prohibição ou á repressão dos crimes, a bem da segurança da sociedade e da defesa nacional. Assiste-lhe, por outro lado, o direito de impedir a entrada, em seu territorio, dos individuos indesejaveis, perigosos á manutenção da ordem social. Effectivamente, nos termos do art. 1 da lei n. ${ }^{\circ} 4.247$, de 6 de janeiro de 1921, ao governo é licito impedir a entrada no territorio nacional de todo o estrangeiro expulso de outro paiz, ou tido como elemento pernicioso á ordem publica, ou evadido de outro paiz por ter sido condemnado por crime de homicidio, furto, roubo, bancarrota, falsidade, contrabando, estellionato, moeda falsa ou lenocinio. Bem assim de todo o estrangeiro mutilado, cego, louco, mendigo, portador de molestia incuravel ou contagiosa grave. De todo o estrangeiro de mais de sessenta annos de edade. $\mathrm{E}$ de toda a estrangeira que procure o paiz para entregar-se á prostituição. 
Para esse fim, a policia maritima visita os navios a vela ou a vapor, que entrem ou sáiam dos portos nacionaes, excepção feita dos navios de guerra nacionaes ou estrangeiros. Fiscaliza o embarque e o desembarque dos passageiros. Detem aquelles cuja captura houver sido determinada pelas autoridades competentes. Exerce toda a vigilancia nos portos, caes, ilhas, praias, docas e ancouradouros, sem prejuizo das attribuições conferidas ás autoridades aduaneiras.

A visita de policia, constante de uma verificação minuciosa da lista dos passageiros em desembarque e dos em transito, póde ser feita a qualquer hora do dia e da noite e immediatamente depois da visita da saude.

b) pela policia sanitaria, indispensavel para verificar se o navio tem a sua carta limpa. E' a visita da saude. Desdobra-se em innumeras providencias prophylacticas. Todo o navio deve trazer a sua carta de saude, mencionando o seu nome, o do seu commandante, o numero de tripulantes e de passageiros, a natureza do carregamento, o estado sanitario do porto de procedencia, as suas condições sanitarias no momento da partida e outras mais formalidades. Se a carta de saude consignar ausencia completa de molestias infectuosas, no porto de procedencia e nos de escala, ella se classificará como limpa; em caso contrario, como suja.

A visita da saude consiste num exame externo e em interrogatorios: antes della, nenhuma autoridade pode atracar a bordo; e, depois della, o commandante recebe o bilhete de livre pratica, para atracar ou desembarcar os passageiros.

Para a facilidade desta visita existem os ancouradouros, em que os navios são obrigados a fundear:

o de visita, ancouradouro de franquia das capitanias e no qual se faz á visita de saude;

o de vigia, em que os navios devem estar em observação, quando suspeitos de trazerem a bordo algum germen de molestia contagiosa, ou passageiros e tripulantes atacados de molestia suspeita; 
o de isolamento, quando os navios provierem de portos infeccionados ou quando se tenha verificado a bordo algum obito suspeito. Neste caso, elles alli permanecerão afim de purgarem a sua quarentena, pelo tempo determinado pela policia, ou a de mera observação, ou a de rigor, conforme o caso.

c) a policia aduaneira, a destinada a realizar o lançamento, a fiscalização e a cobrança dos impostos e taxas fixados por lei. Tambem começa por uma visita: a da alfandega, que começa ás sete horas da manhã e póde ir até ás nove da noite. Exerce-se particularmente na carga e na descarga dos navios e póde confiscar as mercadorias irregularmente recebidas ou expedidas de bordo. Para isso, os navios devem apresentar o seu manifesto, de que conste o seu nome, classe, tonelagem, nacionalidade, nome do capitão, porto de sahida, portos de escala, porto de destino e em que se consignem a qualidade, a quantidade, o peso e a medida de todas as mercadorias transportadas.

Para os navios navegarem livremente, devem receber o passe ou despacho maritimo. Sem este ficam impossibilitados de proseguir na viagem, que a policia poderá impedir, em caso de desobediencia, com o emprego de força.

7. - A DIVISÃO DO COMMERCIO MARITIMO - Da divisão do oceano em mar alto e em mar territorial, resulta a do commercio maritimo em:

a) commercio de longo curso, ou commercio de alto mar, ou commercio internacional;

b) commercio de pequeno curso, ou, mais commumente, o commercio de cabotagem.

Desnecessario é encarecer a importancia desta divisão, por intuitiva, desde que o alto mar é livre ao commercio internacional e que o mar adjacente, a faixa que corre ao longo da costa, é territorial.

8. - A NAVEGAÇÃO MERCANTE BRASILEIRA Dividiu o decr. n. ${ }^{\circ} 17.096$, de 23 de outubro de 1925, a navegação mercante brasileira, em: 
a) navegação de longo curso: a realizada entre os portos brasileiros e os portos estrangeiros, excluindo-se destes os portos do rio da Prata, da costa das Guyanas, os dos rios e lagôas communs ao Brasil e outras nações;

b) navegação de grande cabotagem: a praticada entre os Estados do Brasil, por navios de mais de 700 toneladas brutas;

c) navegação de pequena cabotagem: a feita entre portos maritimos de um Estado, por navio não excedente de 700 toneladas brutas, podendo extender-se aos dos Estados limitrophes e aos de que com estes se limitarem, desde que façam escala pelos portos secundarios e principaes intermediarios;

d) navegação interior: a effectuada nos portos, rios, canaes e lagôas do paiz, mesmo abrangendo mais de uma circumscripção;

e) navegação exterior: a entre portos do litoral brasileiro e os portos do rio da Prata, da costa das Guyanas e vice-versa.

f) navegação fluvial-exterior: a nos rios, canaes e lagôas de que o Brasil e outras nações sejam ribeirinhos.

A navegação de longo curso é a de alto mar, a do commercio maritimo internacional. As outras são nacionaes e desdobram-se no mar territorial, ou nos rios, canaes e lagôas.

Dellas a mais importante é a de cabotagem: a que, no conceito da lei, tem por fim o commercio directo de mercadorias, nacionaes ou nacionalizadas, entre os portos maritimos e fluviaes brasileiros.

9. - A NAVEGAÇão DE CABOTAGEM - Dispoz a Constituição Federal, no art. $13, \S$ unico, que a navegação de cabotagem será feita por navios nacionaes. Instituiu, em favor destes, um privilegio.

Não se permitte, portanto, e sob pena de contrabando, o commercio de cabotagem aos navios estrangeiros; mas, e 
no decr. n. ${ }^{\circ} 17.096$, de 28 de outubro de 1925, ficou expresso, podem elles dar entrada em um porto por franquia e sair dentro do prazo regulamentar, ou arribar para desembarcar naufragos ou doentes, ficando, neste caso, isentos de imposto, ou entrar e sair com a mesma carga, no todo ou em parte despachada para consumo ou reexportação. Licito lhes é transportar de uns para outros portos brasileiros, passageiros de qualquer classe ou procedencia, suas bagagens, animaes, volumes classificados como encommendas de peso não superior a cinco kilos e valores amoedađos. Tambem podem receber em um ou mais portos nacionaes generos destinados á exportação para fóra do paiz. Ou, por autorização do governo, levar soccorro de um a outro porto do paiz, nos casos de fome, peste ou outra qualquer calamidade. Bem assim transportar quaesquer cargas de um para outro porto nacional, nos casos de guerra externa, commoção intestina e prejuizos causados á navegação e commercio maritimo nacional, por bloqueio de forças estrangeiras, embora não haja declaração de guerra, desde que o poder publico, julgue conveniente, ou, ainda, carregar e descarregar mercadorias ou objectos pertencentes á administração publica.

Assim, com fundamento no art. 5 , b, do dec. n. ${ }^{\circ} 10.524$ de 23 de outubro de 1913, o governo, em razão do estado de guerra entre o Brasil e a Allemanha, permittiu aos navios estrangeiros a navegação de cabotagem.

I. - Conferindo aos navios nacionaes o privilegio da navegação de cabotagem, teve o legislador constituinte por intuito o desenvolvimento da industria das construcções navaes e estimulo para o progresso da marinha mercante, como reserva da marinha de guerra e sua mais efficiente collaboradora. Encarou o problema não somente sob o ponto de vista economico, senão tambem sob o ponto de vista politico nacional.

A idéa da nacionalização da navegação de cabotagem não constava do projecto constitucional formulado pelo Governo Provisorio. Nem occorreu á commissão dos vinte e 
um. Surdiu no plenario, por proposta de Baptista DA Motra, deputado fluminense. Rejeitada, em primeira discussão, renovou-a, na segunda, vindo a incorporar-se au texto constitucional. Mas não sem a opposição do presidente do Congresso Constituinte, Prudente de Moraes. Teve elle ao seu lado a bancada paulista. Atacaram a emenda Bernardino de Campos e Moraes Barros. O problema, sustentou aquelle, com o apoio de Campos Salles, não era para ser resolvido na constituição. "Fechemos a porta da Constituição ao privilegio", dizia, "deixemol-a, porém, aberta á solução mais conveniente a tomar em lei ordinaria, quer pela liberdade, quer pela protecção" (8).

No mesmo dia da promulgação da carta repunblicana, pronunciou LEOPOLDo DE BulHões um discurso revisionista. Indicou como um dos pontos a rever o reestabelecimento da liberdade de navegação de cabotagem, que veiu a constituir um dos articulados do programma revisionista do partido dissidente chefiado por Prudente de Moraes.

A questão ainda provoca controversias. Fez bem o congresso constituinte, pondo o pavilhão nacional fóra de concurrencia, quanto á navegação costeira? Ou fez mal?

A verdade, responde Aurelino Leal, "a verdade é que o privilegio não transmittiu á cabotagem o influxo de um prompto desenvolvimento. A industria correlata apenas se ensaia. Não se deve essa condição apenas á falta de população. Em primeira linha, deve ser enumerada a falta de animação do governo, intelligentemente feita, subvencionando a fundação de estaleiros, premiando bons especimens de construcção, mantendo escolas praticas de aprendizado maritimo. O simples monopolio, num paiz de grandes deficiencias contemporaneas, não podia, só por si, ter a virtude de resolver o problema. Elle devia ser o vehiculo, a base, ou por outra, a formula para a solução do problema.

(8) Agenor De Roure, A Constituinte Republicana, vol. 2, pag. 633 . 
Porque a verdade é que a idéa de privilegio não repugna ao caso" (9).

Tem sido praticada em muitos paizes, com os mesmos propositos que ditaram a sua introducção no systema constitucional brasileiro. Nacionalizaram a cabotagem a França, a Allemanha, a Austria-Hungria, a Noruega, Portugal, a Bulgaria. Levou a Hespanha, por uma lei de 1909, o seu rigorismo ao ponto de considerar como de cabotagem as communicações com as colonias hespanholas do norte da Africa e com certos portos em que existe a representação consular hespanhola.

O monopolio da cabotagem, no exprimir-se de Georges RIPERT, carece de grande importancia. Em França, pouco se desenvolveu, peiada pelas tarifas differenciaes das estradas de ferro, essa navegação. Muito contribuiram para a sua estagnação os serviços de melhoramentos de portos secundarios. Não obstante, reconhece, seria perigosa a suppressão do privilegio (10).

Outros paizes, como a Italia, a Grecia, a Suecia, a Dinamarca, a Argentina, adoptaram outra politica. Permittem a cabotagem aos navios dos paizes em que ella fôr livre.

No projecto do codigo commercial, defendeu INGLEZ DE Souza a nacionalização da cabotagen. "Se ha no Brasil", escreveu, "industria que mereça protecção efficaz e constante é inquestionavelmente a da navegação. Sabiamente a nossa Constituição Politica indicou a rota a seguir pelas leis ordinarias, consagrando o privilegio da cabotagem dos navios nacionaes. Todos os argumentos theoricos em favor da liberdade industrial, sob este ponto de vista, têm de ceder ao grande interesse nacional de desenvolver cada vez mais a nossa marinha de commercio, não só em razão da nossa situação geographica, retirando as commu-

(9) Aurelino Leal, Theoria e Pratica da Constituição Brasileira. vol. 1, pag. 191.

(10) Georges Ripert, Droite Maritime, vol. 1, pag. 438, n. 160. 
nicações dos nossos numerosos portos de mar e a navegação e commercio dos nossos grandes rios, como pela necessidade de defesa de nossa extensa costa maritima, fazendo da marinha mercante a auxiliar valiosa da marinha de guerra, pelo serviço de transportes, de avisos e vigias, e pela formação de marinheiros que virão a constituir uma reserva importante para o recrutamento da marinhagem de guerra. Nem foi outra a politica seguida pelas grandes nações da Europa que, dominando hoje o commercio oceanico, e não mais receiando a concorrencia, procuram nos principios liberaes e na innovação das regras juridicas o meio de perpetuar a sua superioridade, impedindo que os povos, menos adeantados industrialmente, possam libertar-se da sua influencia" (11).

II. - A navegação dos rios e aguas interiores do Brasil é permittida a todas as nações, de accôrdo com as leis em vigor, e ás nações limitrophes, nos termos das convenções e tratados.

Os rios interiores, os que fluem dentro do territorio do paiz, se as suas nascentes e a sua foz se acharem dentro dos limites deste, estarão submettidos, exclusivamente, á sua soberania. Se, porém, fôrem successivos, com atravessarem territorios de mais de um paiz, cada um exercerá a sua soberania sobre a parte comprehendida dentro do seu territorio. Se fôrem limitrophes, ou contiguos, a soberania de cada paiz estender-se-á até a linha media ou eixo do canal principal, o thalweg. Nestes dois ultimos casos, o commercio fluvial depende das convenções e tratados, pois é de mistér considerar os interesses dos diversos paizes, o que dá a taes rios um caracter internacional.

O mesmo principio applica-se aos lagos interiores e contiguos, pois a cada paiz pertence a parte entre as linhas que ligarem os extremos das respectivas testadas ao centro, salvo convenção em contrario.

(11) H. M. Inglez De SouzA, Projecto de Codigo Commercial, introducção, vol. 1, pag. 79 . 
Varios tratados, regulando a navegação e o commercio pelos nossos rios interiores foram assignados pelo Brasil e as republicas sul-americanas e, até, reconhecendo-lhes o condominio, como aconteceu com o Uruguay, a proposito da lagôa Mirim, e isso por deliberação espontanea do governo brasileiro, inspirado pelo seu grande chanceller Barão do Rio Branco, nos termos do tratado de 30 de outubro de 1909. Rectificou-se a linha divisoria dos dois paizes, fixando-a por varias rectas, mais ou menos medianas, que, da embocadura do rio Jaguarão, vão dar no extremo sul da lagôa.

Consideram-se como do territorio nacional os golfos e bahias que podem ser dominados pela artilharia posta em terra firme ou em ilhas, ilhotas ou bancos da costa.

Até 1851, somente a marinha nacional podia navegar nos rios do Brasil. Dahi por deante foram, a pouco e pouco, sendo abertos ao commercio estrangeiro. Naquelle anno, mercê de um tratado, ao Perú foi permittido fazer pelo Amazonas até ao mar a sua navegação e o seu commercio. Em 1866, esse grande rio e outros foram franqueados ao commercio de todas as nações.

Outras convenções foram posteriormente effectuadas entre o Brasil e a Bolivia, a proposito da navegação dos affluentes do rio Amazonas, contiguos aos dois paizes; entre o Brasil, o Uruguay, a Argentina, a França e a Inglaterra, acerca do plano da livre navegação e commercio dos rios Paraguay e Paraná.

10. - AS RESTRICÇôES AO COMMERCIO MARITIMO - Soffre o principio da liberdade do commercio maritimo, pois, innumeras restricções. $\mathrm{E}$ isso tanto em tempo de paz como no de guerra. Neste mais do que naquelle.

Decorrentes do considerarem-se os mares adjacentes como prolongamentos dos territorios por elles banhados, até á chamada linha de respeito, e do exercerem nelles os Estados ribeirinhos a sua jurisdicção civil e penal, ou, melhor, a sua soberania, em toda a plenitude, as principaes são as já estudadas: a interdicção da cabotagem aos na- 
vios estrangeiros, a visita da saude, a visita de policia, a visita aduaneira, a apresentação da carta de saude, a exhibição do manifesto, a entrega do passe. O pagamento do imposto de ancoragem, ou de pharóes. $O$ de praticagem. $\mathrm{E}$ outros e certas taxas, tidas como direitos de navegação e a que a industria dos transportes maritimos está sujeita e cujo producto ora reverte em favor dos cofres publicos, ora em beneficio de collectividades ou instituições de beneficencia, constituindo, neste caso, um imposto de assistencia. Imposto de docas, imposto sanitario, imposto de chancellaria, eis outras modalidades de contribuições a que os navios ficam obrigados. Para a sua cobrança e fiscalização, podem as autoridades praticar todas as medidas $\mathrm{e}$ diligencias, previstas nos regulamentos.

Portos existem, entretanto, em que os navios podem entrar, sem se subordinar á obrigação do pagamento dos impostos aduaneiros. São os portos francos. Os outros são os portos livres. Não se fez, ainda, entre nós, o estabelecimento e a regulamentação dos portos francos: os nossos portos são livres. A utilidade daquelles para o commercio em geral tem sido demonstrada e varias campanhas têm sido feitas, mas sem resultado. Outros pretendem a demarcação de zonas francas nos portos livres, em que as mercadorias possam permanecer depositadas, livres de impostos, exigiveis sómente quando ellas forem levantadas para entrar no commercio.

I. - Incluem alguns, entre as restricções do commercio maritimo em tempo de paz, o bloqueio pacifico, o arresto e o embargo de principe. São, entretanto, actos de hostilidade e fazem parte do capitulo das represalias, em direito internacional publico.

O bloqueio pacifico, tambem chamado de bloqueio simples, ou de bloqueio commercial -- cuja legitimidade tem sido negada por alguns publicistas, mas que tem sido empregado, mesmo em nossos dias - é meio violento, por via do qual constrange uma nação a outra, impedindo o seu commercio com as outras nações, a reparar 
injurias, a reconhecer direitos ou a não praticar actos considerados prejudiciaes ou ruinosos.

$\mathrm{O}$ arresto é a captura de navios do Estado offensor ou de seus subditos, nos mesmos casos e para os mesmos fins em que se justificaria o bloqueio pacifico; e o seu desfecho se dá, sobrevindo a reparação, pela restituição dos navios; não se dando, pelo seu confisco. Haver-se-á como presa bellica no caso de declaração da guerra.

O embargo de principe consiste na prohibição da saida do porto de navios de toda a especie, por uma necessidade publica, como a de impedir que sejam conhecidas fóra providencias e operações militares, cuja divulgação seria prejudicial ao Estado (12).

II - Em tempo de guerra, as restricções são maiores e mais efficazes. A captura ou presa. A visita. A angaria. $\mathrm{O}$ bloqueio. Estas medidas de guerra referem-se apenas ao commercio ou navegação maritima. Como medida de restricção á liberdade do commercio, que tomou, quando foi da conflagração européa, uma extensão vastissima, e foi de uma incontestavel efficiencia, ha a destacar a lista negra, a black list dos inglezes. O lemma era na guerra como na guerra. Esta não era apenas contra a Allemanha, mas contra os allemães. Destinava-se a impedir o seu commercio. Os alliados não podiam commerciar com os allemães, nem com os que com elles negociavam. Para isso, organizou-se a lista negra.

Outras medidas de represalia foram postas em campo, restringindo o commercio. Assim, a lei n. 3.393, de 6 de novembro de 1917, permittiu ao governo, a titulo de represalia, além de outras medidas, a retenção, nas alfandegas e entrepostos publicos e particulares, de mercadorias destinadas a inimigos e encontradas nos respectivos armazens, podendo ordenar a sua venda. Recolher-se-ia o producto ao Thesouro Nacional, onde seria inscripto com todas

(12) Lafayette Rodrigues Pereira, Principios de Direito In. ternacional, vol. 2 , pag. $43, \S 295$, e pag. $46, \S 298$. 
as especificações, como garantia das indemnizações pelos prejuizos causados pelo inimigo á nação ou aos particulares. Prohibiu as relações commerciaes entre nacionaes e estrangeiros residentes no Brasil com subditos inimigos residentes no estrangeiro, quer se tratasse de relações directas ou por intermedio de bancos, casas bancarias, commerciaes ou particulares estabelecidas aqui, ou em paizes neutros, sob pena de multa de 1:000\$000 a 3:000\$000 e de apprehensão dos effeitos dessas transacções. Suspendeu a exportação, para o estrangeiro, de mercadorias e bens de qualquer especie, de propriedade do inimigo, inclusivé titulos, dinheiro, prata e ouro amoedado. Considerou propriedade inimiga os estabelecimentos commerciaes ou industriaes, associações, sociedades, inclusivé as anonymas, bancos, usinas ou armazens, sempre que a totalidade do respectivo capital, ou a sua maior parte, pertencesse a subditos inimigos, fosse onde fosse a respectiva séde, no Brasil ou no estrangeiro. Concedeu, durante o estado de guerra, ao brasileiro ou ao estrangeiro, não inimigo, socio de um inimigo em qualquer sociedade em nome collectivo, capital ou industria, ou em commandita, o direito de promover a dissolução e liquidação do contracto de sociedade. E accrescentou que, no caso de liquidação, o governo poderia ordenar o recolhimento do producto ao Thesouro Nacional, em deposito, resalvados os direitos dos nacionaes e subditos estrangeiros não inimigos, e que do mesmo, a seu juizo, pudessem os subditos inimigos retirar, mensalmente, para alimentos, na fórma da legislação civil, as quantias que fossem julgadas sufficientes.

Ficou, ademais, autorizado o governo a declarar sem effeito, durante o periodo da guerra, os contractos e operações celebrados com subditos inimigos, individualmente ou em sociedade, para fornecimentos e obras publicas de qualquer natureza e, bem assim, todos os que julgasse lesivos aos interesses nacionaes, podendo, ainda, entrar em accôrdo com os Estados para a revisão dos contractos existentes de concessões de terras publicas, e rescindil-os, assumin- 
do a União o onus das indemnizaçôes, respeitados os direitas dos colonos ou proprietarios, já effectivamente localizados.

\section{II}

\section{O NAVIO}

11 - O CONCEITO DO NAVIO - Navio ou embarcação é toda a construcção de madeira ou ferro, movida por força do vento, de vapor ou de electricidade, destinada a correr sobre as aguas, e apropriada para receber a bordo mercadorias ou pessôas, afim de transportal-as de um porto para outro. Adoptando o conceito de LEwi, definiu-o INGLEZ DE Souza como sendo toda a construcção adaptada á industria da navegação (13).

Na sua accepção mais geral, diz Ferreira Borges, a expressão navio "designa toda a embarcação de mar, porém em particular é o nome que se dá ás embarcações empregadas no commercio" (14). As duas expressões são synonimas, pois, no ensinamento do mesmo commercialista, a palavra embarcação "significa tambem todo o vaso, que serve na navegação".

O codigo de commercio ora emprega uma, ora outra das duas designações. Assim, o titulo primeiro da parte segunda se epigrapha: "das embarcações", mas o titulo segundo é o "dos proprietarios, compartes e caixas de navios" e o terceiro trata "dos capitães ou mestres de navio" No texto, entretanto, sem nenhum criterio differencial, se topa com as duas expressões.

Tratando do mesmo navio, e no desenvolvimento do mesmo assumpto, os regulamentos, como aconteceu com o

(13) H. M. Inglez de Souza, Prelecções de Direito Commercial, pag. 196.

(14) José Ferreira Borges, Diccionario Juridico-Commercial, pags. 173 e 323 . 
decr. n. 16.197, de 31 de outubro de 1923, nos arts. 363 e 364 , empregaram as duas expressões.

Esboçou Tancredo Burlamaqui uma distincção. Quando o transporte de passageiros e de mercadorias se faz "pelos mares, nas proximidades das costas, nos rios, lagos, ou canaes, obedecem elles a preceitos proprios que os fazem distinguir dos que o executam com uma tonelagem inferior no trafego do interior dos portos, os quaes estão sujeitos a imposições de ordem inteiramente diversa. A estes é que geralmente se dá o nome de embarcações, reservando-se para os demais a designação de navios" (15).

Regulando a execução dos contractos de hypotheca naval, o decr. n. 15.788, de 8 de novembro de 1922, no art. 3 considera navio "toda construcção nautica destinada á navegação de longo curso, de grande ou pequena cabotagem, apropriada ao transporte maritimo ou fluvial".

Teria tido o intuito de fazer distincção? De, considerando como navio apenas o que se ajustar ao conceito exposto, reputar qualquer outra como embarcação e de, como tal, consideral-a não susceptivel de hypotheca? Pois não é exacto que, estipulando serem susceptiveis do contracto de hypotheca os navios, posto que ainda em construcção, o codigo civil, no art. 825, accrescentou reger-se essa hypotheca pelo nelle disposto e nos regulamentos especiaes, que sobre o assumpto se expedissem? Não deixou, portanto, a cargo dos regulamentos conceituarem-n'o? Não deu ao poder executivo a faculdade de determinar quaes os navios susceptiveis da hypotheca, ou em razão do seu destino, ou em vista da sua tonelagem? Não tem elle, pois, competen-

(15) Tancredo Burlamaqui, Manual de Policia de Navegação Maritima e Fluvial, pag. 16.

- O projecto do codigo commercial, art. 284, esclarece. Quando emprega a palavra navio, entender-se-á a embarcação destinada á industria da navegação. A palavra embarcação estende-se a toda a construcção destinada a correr sobre as aguas, conduzindo pessoas cu cousas. 
cia para distinguir o navio da embarcação, somente aquelle sujeitando á hypotheca?

No direito francez, effectivamente, o navio de mar é le navire e o que navega nos rios le bateau. Pouco importa a tonelagem.

O decr. n. 19.096, todavia, como navio considera não sómente a construcção nautica destinada á navegação de longo curso, de grande ou pequena cabotagem, apropriada ao transporte maritimo, senão, tambem, ao transporte fluvial.

O criterio francez não se presta, entre nós, para determinação do que se deve entender por embarcação. E os regulamentos em vigor não fornecem elementos seguros para resolvel-o, antes manifestam decidida preferencia pelo termo embarcação, ainda referindo-se ao navio mercante de alto mar e de grande tonelagem.

Quando, no emtanto, mencionam a bellonave, uniformemente a designam por navio de guerra.

12 - A DIVISÃO DO NAVIO - Posto indivisivel, compõe-se o navio de duas partes: o casco e os accessorios.

O casco comprehende os costados, a quilha, a mastreação e o leme.

$O$ velame e tudo o mais que no casco se encontra, indispensavelmente, ao serviço da navegação, em estado permanente, ainda que delle separado temporariamente, constituem os accessorios: membra navis e instrumenta navis, o casco e os accessorios. A estes chamam os italianos de colonna della nave, objectivamente, comprehendendo as provisões, viveres, vitualhas e fundos necessarios para a navegação; e, subjectivamente, a dotação do navio, destinada a prover e renovar aquelles fundos.

Variam os escriptores e os codigos no precisar quaes os elementos, as partes, os utensilios, ou os valores que constituem os accessorios. Já no direito romano se discutia se os escaleres e as chalupas faziam, ou não, parte do navio. Bem assim as munições de bocca e de guerra. 
De estabelecer o codigo de commercio, no art. 468, que todos os aprestos, apparelhos e mais pertences existentes a bordo de qualquer navio, ao tempo de sua venda, deverão comprehender-se nesta, ainda que se lhes não faça menção expressa, salvo ajuste em contrario, concluiu o conselheiro Silva Costa que "a latitude desta disposição permitte considerar como accessorios do navio não só as lanchas, botes, chalupas, como tambem as munições de bocca e de guerra, comtanto que se achem a bordo" (16).

Se assim é no caso de venda, tambem o é no de hypotheca. Nos termos do art. 811 do codigo civil, lei da hypotheca naval, esta abrange todas as accessões e melhoramentos. O decr. n. 15.788, de 8 de novembro de 1922 desenvolveu esse principio, accentuando, no art. 10 , $\S$ unico, fazerem parte integrante do navio os seus accessorios: botes, lanchas, escaleres, apparelhos, aprestos, instrumentos nauticos, machinas, se o navio fôr movido a vapor, fretes, provisões, armas e tudo quanto possa ser necessario e util á sua propulsão e ao transporte de passageiros e cargas, bem como quaesquer melhoramentos no mesmo introduzidos depois da hypotheca.

Assim considerado, no seu corpo e nos seus accessorios, admittida a sua indivisibilidade, ponderou INGLEZ DE Souza, "o systema do direito relativo á industria da navegação maritima, fluvial ou lacustre, assenta sobre a natureza juridica do navio, ao qual, se no estado actual da sciencia e da legislação ainda se não poude dar uma personalidade bem caracterizada, forçoso é reconhecelr uma quasi personalidade juridica, no sentido de tornar o navio o centro de certas relações, como se elle fosse sujeito activo e passivo de direitos, sem prejuizo da objectividade que tem como cousa movel" (17).

(16) José da Silva Costa, Direito Commercial Maritimo, vol. 1, pag. 73, n. 57.

(17) H. M. Inglez de Souza, Projecto de Codigo Commercial vol. 1, introducção, pag. 79 . 
13 - A NATUREZA JURIDICA DO NAVIO - Instrumento de transporte maritimo, tem sido o navio, em quasi todas as legislações, considerado bem movel.

O largo desenvolvimento, attingido pela industria da navegação e pelo commercio maritimo, deu logar a que, embora bem movel, fosse, no emtanto, em certos casos, subordinado a nórmas especiaes ao immovel. Assim, preceituou o codigo do commercio, no art. 478, as embarcações, posto reputadas bens moveis, comtudo nas suas vendas judiciaes se guardarão as regras que as leis prescrevem para as arrematações dos bens de raiz. Dahi a advertencia de Teixeira de Freitas: "Ninguem se illuda com a disposição do codigo de commercio, art. 478. As embarcações são bens moveis, e portanto o proprietario dellas póde alienal-as ou hypothecal-as sem outorga de sua mulher. Esse artigo não altera a natureza de taes bens, manda simplesmente que nas arrematações dellas se observem as solemnidades prescriptas para arrematação dos immoveis" (18).

O navio tem todos os caracteres das cousas moveis; e esta sua qualidade mobiliaria já era reconhecida pelo Digesto, lei 20, 8 , XLIII, Quod vi aut clam: navi, mobili tamen.

Em França, nem sempre foi assim. No seu antigo direito, referem Lyon CaEN ET Renault, o navio era incluido na classe dos immoveis (19), afim de aproveitar as disposições áquella classe applicaveis. Admittia-se, na Bertanha e na Provença, a hypotheca do navio. Um edito de 1666 , porém, de então em deante, o considerou movel, fazendo cessar "um uso que estava abusivamente se generalizando, especialmente nos portos da Provença, de considerar, por

(18) Augusto Teixeira de Freitas, Corsolidação das Leis Civis, vol. 1, art. 49, nota 9, pag. 51 .

(19) Lyon Caen et Renault, Traité de Droit Commercial, vol. 5 pag. 73 , n.' 80 . 
ficção, nos contractos, os navios e toda a sorte de embarcações abaixo de um certo preço, como immoveis"

Por isso, o codigo de commercio, no art. 190, declarou que os navios e as outras embarcações maritimas são moveis, coherente com a noção do art. 528 do codigo civil de serem moveis por natureza os corpos que se podem transportar de um logar para outro, quer se movam por si mesmos, como os animaes, quer possam mudar de logar por effeito de uma força estranha, como os inaminados.

De modo identico ao francez dispoz o italiano, no art. 480: o navio é bem movel. Trata-se, todavia, esclarece A. Sisto, de um movel sui generis, de natureza especialissima. Requer normas diversas das reguladoras das outras categorias de bens moveis (20).

Estudando a natureza juridica do navio, que já se chegou a considerar como uma pessôa juridica de responsabilidade limitada até a importancia do seu patrimonio, reputa o conselheiro Silva Costa, com Vidari, forçoso reconhecerse-lhe a qualidade de movel sui generis, pois "se é cerıo que o navio tem todos os caracteres das cousas moveis, não é menos certo que em torno do navio se agrupam certos predicados que não o deixam confundir com a generalidade das cousas moveis" (21).

Não obstante, o regulamento do processo commercial, o de n. ${ }^{\circ} 737$, de 25 de novembro de 1850 , tratando da penhora, depois de determinar os bens sobre que ella póde recair, e a ordem que nella deve ser guardada, declarou, no art. 512, que entre os immoveis se comprehendem as embarcações, fazendo expressa referencia ao art. 478 do codigo commercial. Mas, evidentemente, exorbitou; o que levou Silva Costa a affirmar que as palavras do regulamento são destituidas de valor juridico, porque contradizem o preceito

(20) A. Sisto, Diritto Marittimo Italiano, pag. 10, n. $^{\circ} 3$.

(21) José da Silva Costa, Direito Commercial Maritimo, vol. 1, pag. $82, \mathrm{n}^{\circ} 67$. 
de lei que regulamentam, além de ferir o rigor scientifico do termo.

O codigo civil, porém, corta a duvida. Classificando os bens, considerados em si mesmos, dividiu-os em moveis e em immoveis. Pelo seu systema, no art. 43 delineado, ha quatro classes de immoveis:

a) os immoveis por natureza: o solo, com os seus accessorios e adjacencias naturaes, comprehendendo a superficie, as arvores, os fructos pendentes, o espaço aereo e o sub-solo;

b) os immoveis por accessão physica artificial: tudo quanto o homem incorporar, permanentemente, ao solo, como a semente lançada á terra, os edificios e construcções, de modo que se não possa retirar sem distruição, modificação, fractura ou damno;

c) os immoveis por accessão intellectual: tudo quanto no immovel o proprietario mantiver, intencionalmente, empregado em sua exploração industrial, aformoseamento ou commodidade;

d) os immoveis por determinação de lei: os direitos reaes sobre immoveis, inclusivé o penhor agricola, e as acções que os asseguram; as apolices da divida publica, oneradas com a clausula de inalienabilidade; o direito á successão aberta - estes, tendo em vista a maior segurança das relações juridicas (22).

Em nenhuma dessas classes incluiu o navio, bem movel, susceptivel de movimento proprio, no exprimir-se do art. 47, ou de remoção por força alheia. Submettendo-o ao regimen hypothecario, nada mais natural, nem mais logico, que o houvesse arrolado entre os immoveis, para os effeitos legaes. Não o fez. Nem, mesmo, se lhe referiu no art. 810, ao discriminar os bens que podem ser hypothecados,

(22) Clovis Bevilaqua, Codigo Civil Commentado, 3." ed., vol. 1. pag. 260 , observ. 3 ao art. 43 . 
e taes sãos: os immoveis; os accessorios dos immoveis, conjuntamente com elles; o dominio directo; o dominio util; as estradas de ferro; as minas e pedreiras, independentemente do solo onde se acham. Fazendo correcções diversas no codigo civil, a lei n. ${ }^{\circ} 3.725$, de 15 de janeiro de 1919 , mandou accrescentar entre os bens que podem ser objectos de hypotheca, o navio. Deixou, dest'arte, em evidencia a sua qualidade de bem movel. Dissipou qualquer duvida que o texto legal pudesse suggerir. Não o poz no rol dos bens immoveis, para os effeitos legaes.

14 - A INDIVIDUALIDADE DO NAVIO - Bem movel, por natureza indivisivel, o navio tem corpo: o corpo do navio, elle proprio, com o seu casco e os seus accessorios, aprestos e apparelhos.

O casco é formado pela quilha, lenho comprido e recto, ou viga de ferro ou de aço, que lhe fórma o fundamento e é a base de todo o seu arcabouço, e pelos costados, que se ajustam á quilha, como, no esqueleto animal, as costellas á espinha.

A prôa é a parte anterior do navio e a pôpa a posterior.

O convés é a area da primeira coberta, e escotilhas as aberturas no convez, que dão entrada para a carga.

Poder-se-ia desdobrar uma vasta nomenclatura, de termos especialissimos, technicos e da giria, das outras partes do navio: os que ahi ficam são os mais usuaes e os dé mais trato neste assumpto.

E tudo isso vem demonstrar ser o navio bem movel, de feitio todo especial. Merece tratamento mais aprofundado, como instrumento do transporte maritimo. Nasce, pela sua construcção, como producto do engenho humano. Tem estado civil. Tem nome. E' baptisado e registrado. Tem domicilio. Carece de passaporte para viajar. Singra os mares. Movimenta riquezas. Põe em contacto os homens de todos os continentes. Vive. Tem nacionalidade, a da sua bandeira. Envelhece, pela sua imprestabilidade, resultante da acção do tempo e do uso, transfigurando-se, ás vezes. 
E chega a morrer, quando não logra vencer o impeto e a furia dos temporaes.

Tem, portanto, individualidade.

15 - O NOME DO NAVIO - Como todo o individuo, o navio deve ter um nome.

Não se lhe permitte o anonymato.

O nome será marcado em ambos os bordos da prôa e da pôpa, onde tambem se indicará o porto do registro. Tanto o nome do navio, como o do porto, serão inscriptos em caracteres de côr clara sobre fundo escuro, ou vice-versa, e ficarão distinctamente visiveis.

As menores letras medirão mais de dez centimetros de altura.

O seu numero official e o indicativo da sua tonelagem registrada gravar-se-ão no vão da escotilha do porão da ré. Conservar-se-ão cuidadosamente, tanto quanto o nome. Não poderão ser modificados. Tambem terá cada navio uma escala, em medida metrica e em pés, denunciadora do calado de agua, marcada de cada lado do talha-mar e do cadaste, em letras romanas ou em algarismos de dois centimetros de altura, no minimo, devendo coincidir as partes inferiores das letras e algarismos com a linha de agua. As letras ou algarismos serão gravados ou pintados de branco sobre fundo escuro ou vermelho.

Marcar-se-á a linha da maxima carga ou de franco bordo, de branco sobre fundo escuro ou vermelho.

Prohibiu a lei franceza de 5 de julho de 1836 a mudança do nome do navio: e o prohibiu em vista das fraudes que, até então, se verificaram, causando prejuizos a afretadores e a seguradores. Fazem Lyon Caen et Renault referencia a uma decisão administrativa, de 1861, permittindo a substituição comtanto que, ao lado do novo, se escrevesse o antigo (23).

(23) Lyon Caen et Renault, Traité de Droit Commercial, vol. 5, pag. 66, n.a 68 . 
O decr. n. 17.096, de 28 de outubro de 1925, entretanto, permitte a mudança, quando tenha passado por transformação no casco, armação ou machina, que alterem os seus caracteristicos anteriores; ou quando, por mudança de proprietario, resolver este dar-lhe outro. O nome é dado pelo proprietario. Deve ser tal que evite qualquer confusão, sendo, por isso, licito alteral-o ou substituil-o.

Em qualquer caso deve preceder autorização da capitania do porto, ou da repartição em que o registro tiver sido feito, depois de deferido o requerimento pelo inspector de portos e costas. Far-se-ão as necessarias alterações no registro, no titulo de registro e no navio.

O nome é conferido, no mais das vezes, solemnemente: é o acto de baptismo do navio.

16 - A TONELAGEM Do NAVIO - A tonelagem do navio é a expressão da sua capacidade interior, calculada por toneladas. A tonelada é medida de unidade do navio e provem a denominação, segundo Valin, do facto do antigo uso nautico de calcular a capacidade do navio pelo numero de toneis de vinho que pudesse transportar, equivalendo o tonel a dois metros e oitenta e tres centimetros cubicos (24).

A operação por via da qual se mede a capacidade do navio chama-se arqueação. Realiza-se a requerimento dos interessados, por empregados das alfandegas ou da repartição que fôr designada pelo governo. Na falta desses funccionarios, por pessôas competentes, que o inspector da alfandega ou administrador da mesa de rendas encontrar na localidade. No estrangeiro, será realizada por pessoas competentes da escolha dos consules brasileiros.

Effectua-se a arqueação, na maior parte dos paizes, pelo methodo inglez de Moorson, existindo, entretanto, outros methodos praticos, como em França.

(24 Julien Bonnecase, Traité de Droit Commercial Maritime, pag. 234, n. $^{\circ} 229$. 
A tonelagem, quanto ao navio de guerra, é o peso do volume de agua que elle desloca, ou do casco com tudo que contem: é a tonelagem de deslocamento. O deslocamento é funcção do calado do navio: tal seja o calado, ou a profundidade a que attingir, por ahi se determinará a sua capacidade, por um processo de planos geometricos, conhecida a sua linha de fluctuação.

Tratando-se de navio mercante, a sua tonelagem - a tonelagem de arqueação, medida da sua capacidade interior, ou de seu volume utilizavel para fretes, passageiros ou mercadorias, serve de base para o lançamento dos impostos que recáem sobre a industria da navegação, dividindose em:

a) tonelagem bruta ou total, quando exprime a somma de todos os espaços fechados e cobertos existentes, tanto por baixo como por cima do pavimento superior do navio;

b) tonelagem liquida, quando exprime o espaço utilizavel do navio, feitas as deducções correspondentes aos espaços destinados exclusivamente aos serviços da tripulação, e os occupados pelo apparelho motor e as carvoeiras.

A tonelada, em taes casos, tonelada de registro, corresponde a cem pés cubicos, ou a dois metros e oitenta e tres centimetros cubicos.

Mas ainda existem a tonelada de fretamento, que é a quantidade, em peso e em volume, por cujo transporte se paga o frete; e a tonelada de capacidade, que não tem valor fixo, destinada a medir a carga que preencher o espaço disponivel do navio.

Com esses dois requisitos: o nome e a tonelagem, estabeleceu-se a individualidade do navio; mas é de mistér, ainda comprovar-lhe a identidade.

17 - A CLASSIFICAÇÃO DOS NAVIOS - Todo o navio, destinado a navegação de alto mar, com excepção somente dos que exclusivamente se empregarem nas pescarias das costas, deve, consoante o art. 460 do codigo de 
commercio, ser registrado, sem o que não será admittido a despacho.

O regulamento das capitanias dos portos, approvado pelo decr. $n .^{\circ} 17.096$, de 28 de outubro de 1925 , dividiu os navios mercantes, que elle, systematicamente, denomina de - embarcações mercantes, em quatro classes.

Primeira classe: as embarcações movidas por machinas de qualquer especie e que se empreguem na navegação de longo curso, de grande cabotagem e na exterior, a saber:

a) as que navegam para o estrangeiro e transportam emigrantes;

b) as que navegam para o estrangeiro e transportam passageiros;

c) as que navegam para o estrangeiro e não transportam passageiros;

d) as de mais de setecentas toneladas brutas, que fazem a navegação exterior ou a de grande cabotagem e transportam passageiros;

$e)$ as de mais de setecentas toneladas brutas, que fazem a navegação exterior ou a de grande cabotagem e não transportam passageiros;

$f$ ) as de mais de duzentas toneladas brutas que fazem a pesca em alto mar;

g) as de recreio, que navegam em alto mar;

h) as destinadas ao serviço de reboque ou salvamento da costa.

Segunda classe: as embarcações movidas á vela, que se empregam na navegação de longo curso, de grande cabotagem e exterior, a saber:

a) as de mais de setecentas toneladas brutas, que navegam para o estrangeiro e transportam passageiros;

b) as de mais de setecentas toneladas brutas, que navegam para o estrangeiro e não transportam passageiros; 
c) as de mais de setecentas toneladas brutas, que fazem a grande cabotagem e navegação exterior e transportam passageiros;

d) as de mais de setecentas toneladas brutas, que fazem a grande cabotagem e navegação exterior e não transportam passageiros;

$e$ ) as de mais de duzentas toneladas brutas, que fazem a pesca em alto mar;

$f)$ as de recreio, que navegam em alto mar;

g) as de regatas, que navegam em alto mar;

Terceira classe: as embarcações movidas por machinas ou a vela e que se empregam na navegação de pequena cabotagem, a saber:

a) as movidas por machinas, de mais de cem toneladas brutas até setecentas, que fazem somente a pequena cabotagem e transportam passageiros;

b) as movidas por machinas, de mais de cem toneladas brutas até setecentas, que fazem somente a pequena cabotagem e não transportam passageiros;

c) as de oito até duzentas toneladas brutas, que fazem a pesca da costa;

d) as a vela, até setecentas toneladas, que fazem somente a pequena cabotagem e transportam passageiros;

e) as de recreio, a vapor ou a vela.

Quarta classe: as movidas por machinas, velas ou remos e que se empregam na navegação interior e na fluvialexterior, a saber:

a) as movidas a machina, de mais de duzentas toneladas brutas, que fazem somente a navegação fluvial ou das lagôas navegaveis e transportam passageiros;

b) as movidas a machina, de mais de duzentas toneladas brutas, que fazem somente a navegação fluvial ou das lagôas navegaveis e não transportam passageiros; 
c) as a vela, até duzentas toneladas brutas, que fazem somente a navegação fluvial ou das lagôas navegaveis e transportam, ou não, passageiros;

d) as a vela, com ou sem machina, até duzentas toneladas brutas, que se empregam no interior dos portos ou das lagôas navegaveis, e não transportam passageiros;

$e)$ as movidas por machinas, até duzentas toneladas brutas, empregadas exclusivamente no interior dos rios, que transportam, ou não, passageiros;

$f$ ) os rebocadores, que podem sahir a curta distancia dos portos;

g) os rebocadores empregados exclusivamente no serviço dos portos, rios ou lagôas;

h) as lanchas a vapor, gazolina, petroleo, alcool, naphta ou electricidade, empregadas exclusivamente no trafego interior dos portos maritimos e dos fluviaes;

i) as dragas, usinas e officinas fluctuantes;

j) as cabréas, guindastes e bate-estacas;

k) as barcas de agua e cisternas;

l) os lameiros;

$m$ ) as embarcações a vela e a vapor, a gazolina, a alcool, a naphta, a petroleo ou electricas, a serviço de repartições publicas federaes, estaduaes, municipaes e das praticagens;

n) as embarcações a vela ou a remos, a serviço das repartições publicas federaes, estaduaes, municipaes e de praticagens;

o) as embarcações a vela, ou a remos, empregadas exclusivamente no trafego dos portos, rios e lagôas, em transporte de passageiros e bagagens ou pequeno commercio;

p) os pontões, saveiros, catráias, chatas, alvarengas e embarcações sem motor proprio;

q) as embarcações de regatas a vela, no interior dos portos; 
r) as embarcações de regatas a remos;

s) os sinos hydraulicos, cozinhas fluctuantes e fluctuantes;

t) as embarcações até oito toneladas brutas, que fazem a pesca no interior dos portos;

u) as embarcações que fazem a pesca em lagôas, lagos e fluvial;

v) as pequenas embarcações, taes como chalanas, igaralés, montarias, cahiques, etc., applicadas no interior de portos e rios e lagôas, para uso exclusivo do proprietario, sem poder applical-as ao pequeno commercio.

18 - O REGISTRO DO NAVIO - Com excepção das embarcações de recreio, que navegam em alto mar e das destinadas ao serviço de reboque ou salvamento da costa, na primeira classe; ao de recreio e de regatas, que navegam em alto mar, da segunda classe - as outras embarcações ou navios serão registrados. Bem assim ás embarcações ou navios, movidos por machinas, de mais de cem toneladas brutas até setecentas toneladas, que fazem somente a pequena cabotagem, transportando passageiros, ou não, da terceira classe; e as movidas por machinas, de mais de duzentas toneladas brutas, da quarta classe, que fazem somente a navegação fluvial ou das lagôas navegaveis, transportando passageiros, ou não.

Afóra estas, obrigadas ao registro, as outras embarcações, exceptuando-se as jangadas, ficam sujeitas a arrolamento.

O codigo de commercio impunha o registro somente aos navios destinados á navegação em alto mar, salvante os empregados exclusivamente nas pescarias das costas. 0 regulamento das capitanias dos portos estendeu-o tambem aos destinados á pequena cabotagem e aos que fazem a navegação fluvial ou lacustre.

$O$ registro será feito na capitania do porto em que tiver domicilio o proprietario do navio; ou, nos portos em que não existir capitania, na delegacia da capitania do porto, 
ou na alfandega, mesa de renda ou qualquer outro posto fiscal, quando nem aquellas delegacias existirem.

Quando o proprietario residir fóra do paiz, o registro será feito no porto de residencia do seu representante.

Antes de proceder-se ao registro deverá ser o navio, ou embarcação, vistoriado na fórma regulamentar.

$O$ registro será requerido a autoridade competente pelo proprietario do navio, ou por seu representante legal. Se forem muitos os proprietarios, será o requerimento feito pelo que tiver maior quinhão, ou pelo representante da maioria, se forem eguaes os quinhões. $\mathrm{E}$ o requerimento será acompanhado de uma declaração, de que constem:

a) o nome do navio, ou embarcação, seu typo de construcção, sua armação e numero de cobertas, que tiver;

b) as suas dimensões principaes, em medidas metricas, a sua tonelagem em bruto e liquido, comprovada por certidão de arqueação, com referencia á sua data;

c) o logar onde foi construida, os nomes dos constructores, as qualidades dos principaes materiaes empregados na sua construcção e a data em que foi lançado ao mar;

d) o nome do constructor da machina, o typo e a força em cavallos nominaes, o typo e o numero das caldeiras, com indicação de pressão e regimen do systema propulsor e combustivel empregado;

e) a nação a que pertencia, nomes que anteriormente teve e o titulo por força do qual passou a ser propriedade brasileira, se tiver sido construida no estrangeiro;

f) o nome do proprietario ou proprietarios, com indicação da parte que couber a cada um dos associados e seus respectivos domicilios;

g) a especificação do quinhão de cada comparte, e a época de sua acquisição, referindo-se á natureza do titulo, que será exhibido, e sua data;

h) a época de sua acquisição, com referencia á natureza e data da escriptura, que será offerecida; 
i) as lotações dos passageiros de primeira, segunda e terceira classe, determinadas na fórma regulamentar;

j) a lotação de tripulantes.

Mais ou menos, as mesmas disposições dos arts. 461 e 462 do codigo do commercio.

$O$ registro póde ser transferido de um porto para outro, observadas as formalidades regulamentares, caso em que a autoridade, que conceder a transferencia, dará aviso á do novo porto, enviando-lhe copia de todas as indicações relativas ao navio, ou embarcação, mencionando os nomes de todas as pessoas, constantes do registro, com interesse nelle, ou como proprietarios, ou como credores.

19 - O ARROLAMENTO DAS EMBARCAÇõES - $\mathrm{O}$ arrolamento é feito nas capitanias dos portos, afim de se realizar a estatistica das embarcações e de se lhes comprovar a propriedade, mediante requerimento do seu proprietario ao capitão do porto, delegado ou agente, instruido com o documento comprobatorio da propriedade, que poderá ser o recibo do preço da compra, ou, quando construida pelo requerente, a licença para a construcção. O requerimento poderá ser verbal, quando a embarcação fôr de quarta classe, e será gratuito.

Em livro apropriado se lançarão o nome da embarcação, o typo da construcção e armação, as dimensões principaes em medidas metricas, o typo de machina e força em cavallos nominaes, o typo e numero de caldeiras com indicação do regimen e systema propulsor, serviço a que se destina, nome e domicilio do proprietario, lotação e especies de tripulantes. Ao arrolamento deve preceder a vistoria, salvo quando dispensada pelo regulamento, designando-se, nessa occasião, a tripulação, a pressão de regimen, o numero de passageiros e carga que poderá comportar.

$\mathrm{O}$ arrolamento é permanente, mas cancellar-se-á o das embarcações que não renovarem as licenças, durante dois annos, para continuarem a empregar-se no serviço a que 
se destinavam, adquirindo a papeleta e chapa de licença annual, chapa que será fixada em logar visivel.

Nenhuma embarcação poderá entrar em serviço sem estar arrolada e licenciada, sob pena de cem mil reis de multa e de apprehensão, até a legalização de seus documentos, no prazo de dez dias, findo o qual será considerada sem dono, para ser vendida em leilão publico e o producto recolhido aos cofres publicos.

20 - O TITULO DO REGISTRO E DO ARROLAMENTO - Feito o registro ou o arrolamento, a capitania dos portos, ou a repartição que o fizer, expedirá um documento destinado a comprovar a propriedade e a nacionalidade do navio ou da embarcação: o titulo de registro e o do arrolamento.

21 - O REGISTRO DOS CONTRACTOS MARITIMOS - Regulando a execução dos contractos de hypotheca naval, consignou o decr. n. 15.788, de 8 de novembro de 1922, no art. 21, que a sua inscripção se faria em livro especial, a cargo da repartição creada para esse fim, e a averbação no livro do registro naval existente nas capitanias dos portos, ou, em falta destas, nas suas delegacias, nas alfandegas, nas mesas de rendas ou outro qualquer posto fiscal; e nos consulados brasileiros, quando celebrados no estrangeiro.

Mudou, porém, o decreto legislativo n. 5.372-B, de 10 de dezembro de 1927, a denominação dos officios privativos de registro de hypothecas maritimas para a de officios privativos de notas e registros de contractos maritimos. Mandou nelles lavrar e registrar todos os contractos de direito maritimo, quando a escriptura publica fôr substancialmente exigida para a sua validade. Creou, portanto, um notariado ou tabellionato privativo para os contractos maritimos e para o seu registro; e, afim de evitar duvidas, frizou, no art. 2, que "os contractos de direito maritimo, regulados pelo codigo commercial (segunda parte), quando feitos por instrumento particular, serão egualmente registrados nos 
referidos officios, ficando, todavia, isentos desse registro os contractos de fretamento parcial de navio".

$\mathrm{Ou}$, pois, os contractos maritimos são lavrados em notas desse serventuario, que o regulamento, approvado pelo decr. n. 18.399, de 24 de setembro de 1928, subordinou ao juiz federal da respectiva secção, ou ao da primeira vara, se elle tiver mais de uma; ou são nellas registrados.

Ahi temos, pois, dois registros maritimos: o dos navios e o dos contractos a que elles dão logar.

22 - OS EFFEITOS DO REGISTRO E DO ARROLAMENTO - O registro, tanto quanto o arrolamento, não é mais do que a inscripção da propriedade do navio ou embarcação: authentica-a, tornando-a publica e valida erga omnes.

Por essa razão, determina o decr. n. 18.197, de 31 de outubro de 1923 , no art. 424, sempre que se der modificação na propriedade do navio, o capitão apresentará, immediatamente depois da mudança, se ella se der no porto do registro, o respectivo titulo, á capitania, e logo que a elle regressar, se a mudança se der em outro porto, para a devida averbação no respectivo livro, sob pena de não valer contra terceiros.

Nenhuma modificação, que affecte as indicações do registro e outros caracteristicos, poderá ser feita no navio, sem previa licença da capitania dos portos. Tambem não poderá ser desmanchado sem o previo cancellamento do registro, que terá logar, ademais, nos seguintes casos: no de perder o navio a qualidade ou nacionalidade brasileira e no de não haver noticia de seu paradeiro por mais de dois annos.

23 - O REGISTRO PARTICULAR DO NAVIO - Pode-se, ainda, considerar como elemento de individualização do navio a sua classificação, feita por instituições particulares, como o Lloyd. Originou-se em um café que, na rua maritima e commercial de Londres, Tower-Street, explorava Edward Lloyd, e era frequentado pelos negociantes que 
recebiam e expediam carregamentos de navios pelo Tamisa e pelos capitães de navios (25). De um simples ponto de reunião se transformou, a pouco e pouco, num centro de informações maritimas. Veiu, afinal, por força de lei, a converter-se numa corporação, investida de innumeros privilegios. Tornou-se um registro de navios, o archivo obrigatorio de todas as transacções navaes, contendo e fornecendo informações sobre todos os navios lançados ao mar, mercê de um serviço universal, sempre prompto e sempre opportuno. Ganhou grande renome e prestigio.

Instituiu-se, em cada paiz, corporação identica, como o Bureau Veritas, em França; o Germanischer Lloyd's em Berlim; o Registro italiano e outros.

Foi, no Rio de Janeiro, creado o Registro Maritimo Brasileiro, para vantagem das companhias nacionaes de seguros, pois para estas é que tal instituição é da maior relevancia, como aconteceu com o Lloyd na Inglaterra.

24 - A NACIONALIDADE DO NAVIO - Sem embargo de ser instrumento do transporte maritimo, de propriedade privada, o navio mercante é considerado como uma porção fluctuante do territorio nacional. Tem, por isso, nacionalidade, qualidade que põe em relevo a sua identidade e a sua individualidade, e da qual lhe decorrem varias garantias e o privilegio de fazer o commercio de cabotagem. Penetrando em zona de influencia de soberania estrangeira, fica, em verdade, subordinado a uma dupla jurisdicção, em parte submettido a lei de seu pavilhão e, em parte, á lei da nação em cujas aguas se encontre.

Em alto mar, todos os actos, que a seu bordo se passam, cáem sob o imperio da lei de sua nação, tanto quanto nas aguas territoriaes desta. Em aguas estrangeiras, todavia, ficam sujeitos ás leis ahi em vigor, salvo quanto aos crimes a bordo commettidos, de que somente conhecerão as autoridades locaes ou se fôrem graves ou perturbarem a

(25) Paul Govare, L'assurance maritime anglaise, pag. 19. 
tranquillidade publica, ou se o capitão ou o consul brasileiro lhes pedirem a intervenção. Isso, bem entendido, se o crime se praticar entre pessôas da tripulação.

Os contractos celebrados a bordo entre o capitão e pessôas da tripulação, ou entre estas, regulam-se pela lei do pavilhão do navio.

Gosa o navio, portanto, em face do direito internacional, do privilegio da extra-territorialidade.

25 - O NAVIO MERCANTE BRASILEIRO - Determina-se a nacionalidade do navio, que é indicada pelo pavilhão sob o qual navega, pelo direito de cada paiz. Para o navio mercante considerar-se brasileiro, afim de usofruir os privilegios dessa qualidade decorrente, o decr. n. 16.197, de 31 de outubro de 1923, no art. 391, exige:

a) que tenha sido construido no Brasil;

b) que seja de propriedade de cidadão brasileiro, na fórma do art. 69 da constituição, ou de sociedade, ou empresa, com séde no Brasil, gerida exclusivamente por cidadão brasileiro;

c) que sejam brasileiros o capitão, immediato, pilotos, commissarios, medicos, enfermeiros, artifices, mestres, contra-mestres, machinistas, telegraphistas e, pelos menos, dois terços das tripulações do convez, machina e tảifa, respectivamente.

Definindo os seus proprios termos, deu-se o regulamento ao luxo de esclarecer o que, para os seus effeitos, se deve entender pela expressão cidadão brasileiro: as pessôas de ambos os sexos e de qualquer edade e a mulher brasileira, casada com estrangeiro, se, pelo contracto ante-nupcial, além de não haver communhão de bens, lhe couber a administração pessoal e directa dos que lhe forem proprios. Restringiu. Evidente é, no emtanto, que, nesse ponto, incide em censura juridica. São cidadãos brasileiros, e sobre isso é inadmissivel qualquer duvida pelo não poderem as leis ordinarias, e os regulamentos administrativos muito 
menos, revogar a lei primaria e primacial de nossa organização politica; são cidadãos brasileiros os enumerados no art. 69 da Constituição.

Considerou, por outro lado, nacional:

a) a sociedade em nome collectivo, em commandita simples, ou de capital e industria, constituida em territorio brasileiro, não podendo, porém, fazer commercio maritimo de cabotagem, se não tiver como gerente cidadão brasileiro, socio ou não;

b) a sociedade em nome collectivo ou em commandita simples, constituida exclusivamente por brasileiros, fóra do territorio nacional, se tiver o seu contracto archivado no Brasil, a firma inscripta e a gerencia confiada a brasileiros;

c) a sociedade anonyma ou em commandita por acções, constituida em paiz estrangeiro, se, obtida a autorisação para funccionar no paiz, para o territorio nacional transferir a sua séde e tiver por directores ou socios gerentes cidadãos brasileiros.

Pela doutrina, contida no art. 459 do codigo do commercio, sómente poderia gosar das prerogativas e favores concedidos a navio brasileiro, o que, verdadeiramente pertencesse a brasileiro, sem que algum estrangeiro nelle possuisse parte ou interesse, e desde que o seu proprietario fosse domiciliado no Brasil.

Mas esta clausula foi revogada pela lei n. 2.548, de 25 de agosto de 1873 , art. $11, \S 5$, n. 8, que foi regulamentada pelo decr. n. 5.585 , de 11 de abril de 1874, art. 1 .

No regimen republicano, a lei n. 123, de 11 de novembro de 1892, estabeleceu que, para ser considerado nacional, devia o navio ser propriedade de cidadão brasileiro ou empresa com séde no Brasil, gerida exclusivamente por cidadãos brasileiros. Brasileiro deveria ser o seu capitão ou mestre. E a respectiva equipagem constituida, no minimo, por dois terços de brasileiros. 
Sómente em 1896, entretanto, entrou essa lei em execução, pelo regulamento approvado pelo decr. n. 2.304, de 2 de julho de 1896, que assentou as mesmas disposições exaradas no decr. n. 16.197 , de 31 de outubro de 1923, reproduzidas, com pequenas differenças, no decr. n. 15.788, de 8 de novembro de 1922, que regulou a execução dos contractos de hypotheca maritima, art. 3 .

\section{6 - O ABRASILEIRAMENTO DO NAVIO MERCAN-} 'TE ESTRANGEIRO - Pode ser nacionalisado, ou abrasileirado, o navio de construcção estrangeira, legalmente adquirido por brasileiro. O capturado ao inimigo e considerado, de accôrdo com o direito internacional, bôa presa, tambem póde adquirir a qualidade de brasileiro. $\mathrm{O}$ em abandono em alto mar. O confiscado por contravenção das leis brasileiras. $\mathrm{O}$ adquirido por brasileiro em virtude de doação ou venda judicial, ou por qualquer outro dos modos, ou titulos, por via dos quaes se adquire a propriedade de navio.

Em qualquer destes casos, indispensaveis são as condições referentes á nacionalidade dos proprietarios, do capitão e da equipagem.

\section{7 - OS PRIVILEGIOS DO NAVIO BRASILEIRO -} Entre outros, gosa o navio brasileiro dos seguintes favores ou privilegios:

a) o do uso do pavilhão nacional e o direito á protecção dos agentes diplomaticos brasileiros; cional;

b) o da ficção do prolongamento do territorio na-

c) o da isenção do imposto de ancoragem nos portos brasileiros;

d) o da navegação de cabotagem, com algumas isenções de praticas aduaneiras;

e) o de, sendo construido no paiz, proporcionar um premio ao seu proprietario, na razão de $50 \$ 000$ por tone- 
lada, desde que a respectiva arqueação demonstre exceder de cem toneladas.

Desses, como já ficou esclarecido, o mais importante privilegio é o da navegação de cabotagem.

Provando-se, preceitua o art. 457 do codigo de commercio, que algum navio, registrado debaixo do nome de brasileiro, pertence, no todo ou em parte, a estrangeiro, ou que este tem nelle algum interesse, será apprehendido como perdido. Pela apprehensão, e por effeito da venda, passará para o dominio do que o arrematar.

28 - A PERDA DA NACIONALIDADE BRASILEIRA DO NAVIO - Perderá o navio, consoante o disposto no art. 394 do decr. n. 17.098, a nacionalidade brasileira:

a) pela venda a estrangeiro;

b) sendo capturado pelo inimigo, em tempo de guerra, quando a captura fôr considerada bôa;

c) por ter sido confiscado no estrangeiro;

d) por não lhe apparecerem noticias por mais de dois annos;

e) por ter perdido o seu proprietario a qualidade de cidadão brasileiro.

Não sendo, dentro do prazo de seis mezes, a contar da perda da nacionalidade do navio, requerido o cancellamento do seu registro, será considerado como contrabando e, como tal, apprehendido e vendido judicialmente.

Fóra de duvida, a doutrina do art. 467 do codigo do commercio não se applica ao navio pertencente a sociedade anonyma que tenha accionistas estrangeiros, se tiver séde no Brasil e brasileiros forem os seus directores ou administradores. Bem assim se a sociedade fôr commanditaria por acções. Tendo a sociedade personalidade juridica é distincta de seus socios; ella é a proprietaria do navio, e não estes.

Esta conclusão é intuitiva. Está consagrada pelo art. $391, \S$ unico, c), do decr. n. 17.096, de 28 de outubro de 
1925, que considera brasileira a sociedade anonyma ou em commandita por acções constituida em paiz estrangeiro, se tiver archivado o seu contracto no Brasil e para aqui transferido a sua séde, depois de autorizada a funccionar, desde que tenha como directores ou gerentes cidadãos brasileiros.

\section{9 - A NACIONALIZAÇÃO DO NAVIO EM OUTROS} PAIZES - Varia o criterio nacionalizador do navio de paiz para paiz, sem embargo de serem poucos os elementos para a sua determinação.

Para adquirir a nacionalidade franceza, deve o navio pertencer a francezes, pelo menos em sua metade; a equipagem será composta de francezes e de subditos das colonias, tambem por metade, sendo licito aos governadores das colonias augmentar ou diminuir esta proporção. $O$ capitão e os officiaes serão francezes. O acto de navegação de 21 de setembro de 1793 exigia construcção franceza, propriedade integralmente franceza, commando e officialidade francezes e, na equipagem, tres quartos de francezes. Mas essa rigidez foi pouco a pouco amortecendo, por effeito de leis promulgadas em 1845, em 1866, em 1872, em 1882.

Para ser italiano, deve o navio pertencer a italianos ou a estrangeiros na Italia residentes e domiciliados a mais de cinco annos. Se os estrangeiros não estiverem nestas condições, não excederão de um terço. Pertencendo o navio a sociedade, solidaria ou em commandita, della devem fazer parte, figurando na sua firma, alguns italianos, como socios solidarios, ainda que sua séde seja no estrangeiro. Se a sociedade fôr anonyma, na Italia terá a sua séde principal (26).

O navio inglez deve pertencer inteiramente a inglez, ou a naturalizados, ou a sociedades constituidas de accôrdo

(26) Giuseppe Vacaro-Russo, Istituzioni di Diritto Maritimo. pag. $10, n .^{\circ} 5$. 
com as leis inglezas e que, na Inglaterra, ou nas suas possessões, tenham o seu centro principal de negocios (27).

Em face da lei argentina, o navio argentino deve usar o pavilhão nacional, ser commandado por capitão argentino nato ou naturalizado e deve ter, na equipagem, conforIme a sua tonelage'm, no minimo um quarto de argentinos (28).

O codigo commercial portuguez, no art. 486, tem por nacional o navio que, como tal, estiver matriculado nos termos do acto especial de navegação. Segundo este, que foi approvado pelo decreto de 8 de julho de 1863, a nacionalidade do navio portuguez tem como base: a) a sua construcção, que deve ser portugueza; $b$ ) os seus proprietarios e armadores; $c$ ) o capitão e os officiaes que o commandam; d) a equipagem ou tripulação que o monta, que devem, todos ser portuguezes, estes ultimos, o da equipagem, em dois terços, pelo menos (29).

Passando em revista as legislações, verificar-se-á que as regras para a determinação da nacionalidade do navio têm por base:

a) o logar da construcção, considerando-se requisito essencial que esta tenha sido feita dentro do paiz respectivo;

b) a nacionalidade do proprietario;

c) a nacionalidade do capitão e dos officiaes;

d) a nacionalidade da equipagem.

Ora se exige a reunião de alguns, ora de todos esses requisitos, como ficou evidente nos casos especiaes aqui, como exemplos, indicados.

(27) I. M. Stevens, Éléments du Droit Commercial Anglais, pag. 474.

(28) Juan C. Carlomagno, Manual de Derecho Maritimo, pag. 88, n. 307 .

(29) Luiz da Cunha Gongalves, Commentario ao Codigo Commercial Portuguez, vol. 3, pag. 88, n..$^{\circ} 725$. 


\section{A PROPRIEDADE NAVAL}

\section{0 - A ACQUISIÇÃO DA PROPRIEDADE DO NAVIO} - Não sendo o navio, nem para os effeitos legaes, bem immovel, mas, por susceptivel de movimento proprio, ou de remoção por força alheia, nos termos do art. 47 do codigo civil, bem movel; tratado, no concernente á sua propriedade, como se bem de raiz fosse, pois, consoante o art. 825 do codigo civil, é susceptivel do contracto de hypotheca, posto ainda em construcção - como se lhe adquire a propriedade?

Originariamente, pela construcção.

Em regra, é pela occupação, ou apropriação, que se adquire a propriedade: o primeiro occupante é o primeiro dono. Quem se assenhorear, diz o art. 592 do codigo civil, de coisa abandonada, ou ainda não apropriada, para logo lhe adquire a propriedade, não sendo essa occupação defesa por lei.

Mas o navio, producto da industria humana, para ser apropriado, precisa ser construido e o é de materiaes inertes: o seu constructor, portanto, será o seu primeiro proprietario. Ou aquelle que lhe encommendou a construcção. Dahi o reparo de Albert Wahl de ser este mais um modo de creação que de acquisição de propriedade do navio (30).

Derivadamente, ella se opera pelos titulos de direito commum e por outras peculiares ao direito commercial maritimo, ao direito administrativo e ao direito internacional: a venda pelo capitão, a venda forçada em caso de innavegabilidade, o abandono liberatorio e o subrogatorio, a apprehensão e o arbitramento.

(30) Albert Wahl, Précis Theorique et Pratique de Droit Maritime, pag. 30, n. $^{\circ} 38$. 
31 - A CONSTRUCÇÃO NAVAL - E' livre, qual o estabelece o art. 459 do codigo do commercio, a construcção de navios, pela fórma e modo mais conveniente. $\mathrm{O}$ dec. $\mathbf{n} .^{0}$ 17.096, de 28 de outubro de 1925, no entretanto, regulamentando a marinha mercante e a navegação de cabotagem, dividiu os navios mercantes, que poderão ser de qualquer fórma, tonelagem ou porte, e empregar-se na navegação e no serviço que os seus proprietarios julgarem mais conveniente em quatro classes:

I, os movidos por machinas e se empregarem na navegação de longo curso ou de grande cabotagem;

II, os movidos a vela e se empregarem na navegação de longo curso ou de grande cabotagem;

III, os movidos por machinas ou a vela e se empregarem na navegação de pequena cabotagem;

IV, os movidos por machinas, a vela ou a remos e se empregarem na navegação interior.

Nenhum navio, destinado á navegação de longo curso e de grande cabotagem, será, dil-o o art. 228 , construido dentro do paiz, sem que preceda licença da capitania, a approvação dos planos de construcção pela Directoria de Portos e Costas, que ouvirá a Directoria de Engenharia Naval, devendo ser indicado o estaleiro em que tiver de ser construido.

Nos Estados, o requerimento será encaminhado ao director geral dos Portos e Costas pelo inspector do Arsenal de Marinha ou pelo capitão dos portos, sem onus algum para o requerente.

A autorização será gratuita e concedida dentro de sessenta dias e tal se considerará para todos os effeitos se, findo esse prazo, não tiver sido despachada a petição respectiva. Nos Estados, o prazo será de noventa dias.

Os materiaes, apparelhos e systemas, se o navio a construir gozar de favores do governo ou destinar-se a paquete, deverão ser taes que, na eventualidade de guerra, permittam 
a sua transformação em cruzadores, avisos e transportes de guerra.

Por esse motivo é que a autorização ministerial é necessaria, e para a verificação dos demais requisitos legaes.

Nenhum navio, porém, poderá apparelhar-se sem se reconhecer previamente, por vistoria feita na conformidade dos regulamentos em vigor, que se acha navegavel, depositando-se o auto de vistoria antes do registro.

Não consigna o codigo nórmas reguladoras das relações juridicas oriundas da construcção do navio. Este silencio, que em quasi todos os codigos se nota, tem a sua explicação, no sentir de Ripert, em que essas relações escapam da alçada do direito maritimo propriamente dito: são de direito commum (31).

Como a construcção é livre, poderá cada um emprehender a que lhe approuver, desde que tenha os meios necessarios. Nem todos, entretanto, podem fazel-o, pela difficuldade e custo da construcção, que requer estabelecimcntos apropriados, conhecimentos technicos, pessoal adextrado. E' a construcção por conta propria ou por administração, a mais usada nos tempos antigos, até o seculo XVII, mercê da qual a propriedade vae sendo adquirida á proporção que o navio vae apparecendo, podendo, desde então, ser hypothecado, pela regra do art. 756 do codigo civil de que só aquelle que pode alienar póde hypothecar. Nesse caso, as relações do constructor com os terceiros, aos quaes encommenda os materiaes, ou lh'os fornecem, são as do contracto de compra e venda, e as da locação de serviços, ou do contracto do trabalho, com os que lhe emprestam a mão de obra.

Não sendo assim feita a construcção, por conta propria, ou por economia, como dizem os francezes, terá de ser ajustada por empreitada, quer contribuindo o empreiteiro para ella só com o seu trabalho, locatio operis; quer com elle e

(31) Georges Ripert, Droit Maritime, vol. 1, pag. 275, n. ${ }^{\circ} 318$, no Traité Général Theorique et Pratique de Droit Commercial de Edmond Thaller. 
com os materiaes, per aversionem. Reger-se-á o contracto, então, pelas prescripções dos arts. 232 a 240 do codigo do commercio e dos arts. 1.237 a 1.247 do codigo civil.

Quando, em taes casos, quem encommendou o navio lhe adquire a propriedade?

I Se o empreiteiro contribuir só com o seu trabalho ou industria, preceitua o art. 232 do codigo do commercio, perecendo os materiaes sem culpa sua, perecem por conta do dono, e o empreiteiro não tem direito a salario algum, salvo se, estando a obra concluida, o locatario fôr omisso em a receber, ou a cousa tiver perecido por vicio proprio da sua materia.

Decorre do texto que, quando o navio é construido, contribuindo o empreiteiro apenas com o seu trabalho, á medida que os materiaes se vão ajuntando e o casco batido vae elle entrando para o patrimonio de quem o encommendou: todos os riscos, em que não tiver culpa, correrão por sua conta.

Assiste-se, neste caso, como observa Julien Bonnecase, a uma simples transformação de materiaes e como, para isso, não contribue o empreiteiro senão com o seu trabalho, não póde pretender nenhum quinhão na propriedade do navio (32), mas tão somente o pagamento dos salarios ou do preço da empreitada.

Tal o direito que da locação de serviços lhe resulta.

II Quando, está expresso no art. 1.238 do codigo civil, o empreiteiro fornece os materiaes, correm por sua conta os riscos da obra a contento de quem a encommendou, se este não estiver em mora de receber.

Principio identico consignou o codigo de commercio, no art. 231, estipulando que, nos ajustes de locação de serviços, se o locador, official ou artifice se encarregar de fornecer a materia e o trabalho, perecendo a obra antes da entrega,

(32) Julien Bonnecase, Traité de Droit Commercial Maritime, pag. 276, n.' 267. 
não terá direito a paga alguma, salvo se, depois de prompta, fôr o locatario negligente em a receber.

Quem contracta a construcção de um navio, mediante plano estabelecido, fornecendo o empreteiro os materiaes e a mão de obra, só lhe adquire a propriedade depois delle concluido. Pelo texto do art. 234 do codigo commercial, concluida a obra na fórma do ajuste, ou, não o havendo, na fórma do costume geral, o que a encommendou é obrigado a recebel-a.

Viram alguns nesse contracto um aspecto sui generis, de natureza toda especial: vae, no emtanto, ganhando fóros de direito a doutrina que nelle reconhece um contracto de compra e venda de cousa futura ou de venda a entregar. Esposam-n'a, entre outros, Georges Ripert, Julien BorneCASE e Daniel Donjon, salientando este que ella se apoia nas tradições historicas e nos trabalhos preparatorios do codigo civil francez (33). Adopta-a Sergio Loreto Filho, considerando o contracto como de compra e venda, pouco importando, entretanto, que haja o empreiteiro recebido prestações adeantadas do preço: apezar disso, a propriedade do navio em construcção somente se attribue ao que o encommendou depois delle terminado. O navio é uno, indivisivel e não é possivel a entrega parcial. Para conciliar os dois interesses, o do empreiteiro e o do que encommenda a obra, o navio, no caso, introduziu a pratica a hypotheca do navio em construcção em favor deste, para garantia das prestações do preço antecipadamente pagas (34).

Repelle Silva Costa a doutrina dos escriptores francezes para considerar o contracto de empreitada de construcção de navio, em face dos arts. 231 e 232 do codigo commercial, como de verdadeira locação: não é venda a entregar porque, nesta, o objecto existe, emquanto que no caso do

(33) Daniel Donjon, Eléments de Droit Maritime Commercial, pag. 13, n.' 20.

(34) Sergio Loreto Filho, O commercio maritimo no direito internacional privado, pag. 85, n. 23. 
navio em construcção o navio só existirá quando acabado. Dessa doutrina compartilha Alfredo Russel (35).

No contracto de construcção de navio por empreitada, fornecendo o empreiteiro os materiaes e a mão de obra, entendem muitos, este adquire a propriedade do navio originariamente: elle é o constructor; o que lh'o encommendou, adquire-a derivadamente. Daquelle para este se opera a transferencia, depois de concluido o navio e do preço pago, pela sua tradição.

Ora, não é exacto, pelo disposto no art. 1.122 do codigo civil, que, pelo contracto de compra e venda, um dos contrahentes se obriga a transferir o dominio de certa coisa, e o outro, a pagar-lhe certo preço em dinheiro? Pois não assume o empreiteiro a obrigação de construir o navio e de transferir o seu dominio, mediante o pagamento de certo preço em dinheiro?

A objecção de Silva Costa não colhe: nem somente as cousas disponiveis, existentes no acto da celebração do contracto, podem ser vendidas. Se a venda a termo é praticada e reconhecida por varios textos de lei, por que não admittir a venda a entregar? Que impede que alguem se obrigue a vender uma safra futura?

32 - A COMPRA E VENDA DO NAVIO - Póde o navio, como é obvio, ser vendido, como todos os bens patrimoniaes, segundo as normas communs do contracto de compra e venda. Para isso, mister é que o seu proprietario seja capaz e que o acto revista a forma legal. Ha a salientar, entretanto, como especialidades, que lhe são peculiares, quanto á sua causa determinante, que póde provir da vontade ou da coacção. E quanto aos encargos que o acompanham.

A venda, pois, póde ser voluntaria ou forçada.

Voluntaria, quando o ou os proprietarios a effectuam de livre e espontanea vontade; e forçada quando, achando-

(35) José de Silva Costa, Direito Commercial Maritimo, vol. 1, pag. 120, n.' 90, Alfredo Russel, Curso de Direito Commercial Brasileiro, vol. 3, pag. 107, n.` 1.854. 
se o navio, consoante o art. 487 do codigo de commercio, necessitado de concerto e convindo neste a maioria, os socios dissidentes, se não quizerem annuir, serão obrigados a vender os seus quinhões aos outros compartes, estimando-se o preço antes de principiar o concerto. Se não quizerem estes comprar, proceder-se-á á venda em hasta publica.

A venda abrange o navio e os seus accessorios. Ainda que se não faça menção expressa no contracto, resa o art. 468 do codigo do commercio, todos os aprestos, apparelhos e mais pertences existentes a bordo nella se comprehendem, salvo convenção em contrario. Como, emquanto o navio está viajando o frete é accessorio, que delle se separa quando chegar ao porto de destino, tambem o frete o art. 469 do codigo commercial inclue na venda. $\mathrm{E}$ tambem inclue, salvo os direitos dos credores privilegiados, todos os seus encargos, enumerados no art. 470 e que são os seguintes :

a) os salarios devidos por serviços prestados ao navio, comprehendidos os de salvados e pilotagem;

b) todos os direitos de portos e os impostos de navegação;

c) os vencimentos de depositarios e despezas necessarias, feitas na guarda do navio, comprehendido o aluguel dos armazens de deposito dos aprestos e apparelhos;

d) todas as despesas do custeio do navio e seus pertences, que houverem sido feitas para sua guarda e conservação depois da ultima viagem e durante sua estada no porto de venda;

e) as soldadas do capitão, officiaes e gente da tripulação, vencidas na ultima viagem;

f) o premio e o principal das letras de risco tomadas pelo capitão sobre o casco e apparelhos, ou sobre o frete, durante a ultima viagem, sendo o contracto celebrado e assignado antes do navio partir do porto onde taes obrigações forem contraidas; 
g) o principal e o premio das letras de risco tomadas sobre o casco e apparelhos, ou fretes, antes de começar a ultima viagem no porto da carga;

h) as quantias emprestadas ao capitão ou dividas por elle contrahidas para o concerto e custeio do navio, durante a ultima viagem, com os respectivos premios de seguro, quando em virtude de taes emprestimos o capitão houver evitado firmar letras de risco;

i) faltas na entrega da carga, premios de seguros sobre o navio ou fretes e avarias ordinarias e tudo que respeitar á ultima viagem somente.

Isto, bem é de ver, na venda voluntaria.

$\mathrm{Na}$ forçada, que tem logar na fórma do art. 487, em hasta publica, dil-o o art. 477, extingue-se toda a responsabilidade do navio para com todos e quaesquer credores, desde a data do termo de arrematação. Depositada a importancia da venda, passa o navio livre e desonerado para o comprador, subrogando-se no preço os direitos dos credores.

33 - A ESCRIPTURA PUBLICA - A venda do navio, tratando-se de navio brasileiro destinado á navegação em alto mar, só póde fazer-se, ex-vi do art. 468 do codigo commercial, por escriptura publica, na qual, sob pena de nullidade, se deverá inserir o teôr do seu registro, com todas as annotações que nelle houver.

E' uma excepção ao principio constante do art. 134 do codigo civil, de ser a escriptura publica da substancia do acto, ou nos pactos antenupciaes e nas doações, ou nos contractos constitutivos ou translativos de direitos reaes sobre immoveis de valor superior a um conto de réis, exceptuado o penhor agricola.

$\mathrm{E}$ isso mercê da propria natureza do navio destinado á navegação de alto mar e dos negocios que em torno delle se celebram. A escriptura publica é, pois, essencial, da substancia do contracto de venda, ad substantiam: só ella prova o contracto. 
34 - AS OBRIGAÇốS DO VENDEDOR - E' o vendedor, evidentemente, obrigado a entregar o navio ao comprador, no logar e no tempo ajustados. Se o preço não for todo pago, dá-lhe o art. 474 um privilegio, que alcança os juros, por tempo de tres annos, a contar da data do instrumento do contracto, comtanto que seja este registrado convenientemente. Entregue, operada a tradição, subsiste a sua obrigação de garantia e de responder pela evicção.

Impõe-lhe, outrosim, o art. 476, a obrigação de dar ao comprador uma nota assignada de todos os creditos privilegiados, nota que se incorporará á escriptura de venda, em seguimento do registro do navio.

A falta desta declaração, que é de summa importancia, ou de algum credito privilegiado, induz a presumpção de má fé do vendedor e o sujeita ao processo criminal que lhe poderá mover o comprador, se fôr obrigado ao pagamento de algum credito declarado.

Responde, ainda, o vendedor pelos defeitos occultos e, notadamente, pelas condições de navegabilidade do navio.

35 - A VENDA PELO CAPITÃO - Não póde o navio ser vendido, como do exposto resulta, senão pelo seu proprietario, ou por mandatario seu, investido de poderes expressos.

Sem embargo dos inherentes á sua qualidade de commandante do navio e de preposto do seu proprietario, não póde o capitão vender o navio.

Esta prohibição, no emtanto, não é absoluta: comporta uma excepção, constante do art. 531 do codigo commercial, em vista do qual o capitão, que, fóra do caso de innavegabilidade legalmente provada, vender o navio, sem autorização especial dos donos, ficará responsavel por perdas e damnos, além da nullidade da venda e do procedimento criminal que possa ter logar.

Tendo, portanto, sido vendido o navio pelo capitão, para dizer da validade do acto, é essencial verificar: 
a) se o navio, realmente, estava em caso de innavegabilidade;

b) se a prova desse estado foi feita legalmente.

Ha innavegabilidade absoluta e relativa. Absoluta, sempre que, em razão das avarias soffridas, não esteja o navio em condições de permanecer no mar; e relativa, quando forem taes as despezas para pol-o em estado de navegabilidade, que não valha a pena fazel-as. Bem assim quando, por falta de recursos materiaes no logar em que se encontrar, fôr impossivel o seu concerto.

Mas, e o art. 531 é muito claro, a innavegabilidade deve ser "legalmente provada".

Essa prova, no ensinar de INGLEz DE Souza, deve ser feita de accordo com as prescripções do art. 516 do codigo de commercio (36), pelo capitão, ou perante o juiz federal com jurisdicção no porto em que a venda fôr celebrada, ou, se em porto estrangeiro, perante o consul brasileiro, em justificação em que demonstre o estado de innavegabilidade do navio, se absoluta, se relativa, e que a venda foi deliberada de accordo com os officiaes do navio, lavrando-se, no diario da navegação, termo da necessidade da medida tomada.

$\mathrm{E}^{\prime}$ de notar, entretanto, que, sendo a justificação acto de jurisdicção graciosa, a sentença, que a julgar, não faz cousa julgada, de modo que, em acção regular, ou para invalidar a venda, ou para indemnisação de perdas e damnos, o proprietario poderá fazer a prova da navegabilidade do navio.

36 - A ACQUISIÇÃO POR TITULOS DE DIREITO ClVIL, ESPECIALMENTE A PRESCRIPÇÃO - Póde a propriedade do navio ser adquirida por quaesquer dos titulos de direito civil, tanto por actos inter vivos, como causa mortis. Além de por via da construcção e da compra e venda, pela permuta, ou pela doação.

E tambem por successão legitima ou testamentaria.

(36) Inglez de Souza, Prelecções de Direito Commercial, compiladas por Alberto Biolchini, 2." ed., pag. 213. 
I - Bem movel, tratado como immovel, póde a propriedade do navio ser adquirida por via de prescripção. Mas como bem movel? Ou como immovel?

Adquirirá o dominio da coisa movel, reza o art. 618 do codigo civil, o que a possuir como sua, sem interrupção e nem opposição, durante tres annos; e se a posse, accrescenta o art. 619, se prolongar por dez annos, produzira usocapião, independentemente de titulo ou de bôa fé.

O dominio do immovel, porém, é o que diz o art. 551 do mesmo codigo, adquire aquelle que, por dez annos continuos, entre presentes, ou vinte entre ausentes, o possuir como seu, incontestadamente, com justo titulo e bôa fé. Se, todavia, a posse prolongar-se, sem interrupção, nem opposição, por trinta annos, o possuidor adquirir-lhe-á o dominio, independentemente de titulo e de bôa fé, que, em tal caso, se presumem, podendo requerer ao juiz que assim o declare, por sentença, a qual lhe servirá de titulo para a transcripção no registro de immoveis.

Como e quando, pois, se opera a prescripção acquisitiva do navio?

Não lhe é, responde Silva Costa, não lhe é applicavel a prescripção dos immoveis, por isso que não é bem de raiz; tambem não póde estar sujeito á prescripção dos moveis, porque não é mera coisa movel, mas movel sui generis.

Em taes condições, conclue, resta a prescripção extraordinaria de trinta annos, que é, na opinião do Conselheiro Lafayette, subsidiaria. Confirma o argumento tirado da disposição do art. 450 do codigo do commercio, que admitte a prescripção trintennaria em favor do possuidor da coisa por successão, sem má fé (37).

Não existe, entretanto, texto de lei que, para o effeito da prescripção, considere o navio como immovel. Nem, mesmo, o art. 44 do codigo civil. Como tal, declarou os direitos reaes sobre immoveis, inclusivé o penhor agricola, e

(37) José da Silva Costa, Direito Commercial Maritimo, vol. 1. pag. 131, n.' 106. 
as acções que os asseguram; as apolices da divida publica oneradas com a clausula de inalienabilidade, e o direito á successão aberta.

Dahi a assertiva de Sergio Loreto Filho, a que Alfredo Russel adheriu. Havendo justo titulo e bôa fé, a prescripção acquisitiva da propriedade do navio se operará em tres annos, e, não havendo, em dez annos seguidos (38).

A mesma divergencia, em falta de texto expresso, verifica-se no direito francez. Recorrendo aos principios geraes, para fixar a duração da posse do navio que acarreta a acquisição do seu dominio, Lyon CaEn et Renault concluiram que o possuidor de bôa fé, tanto quanto o de má fé, não póde adquirir a propriedade de um navio, senão pela prescripção trintennaria. Georges Ripert, deante do silencio do codigo commercial francez, considerando o navio fóra do direito commum, foi levado a não admittir a prescripção acquisitiva da sua propriedade, mesmo porque, em face de um texto que o declara movel, não se the pódem applicar os principios que regem a prescripção immobiliaria (39). E desafia que se apresente um navio adquirido por via de prescripção, justamente porque a transmissão de sua propriedade está cercada de garantias particulares.

Muitos codigos, não obstante, referem-se á prescripção acquisitiva da propriedade do navio. Assim, o italiano, no art. 918, marca o prazo de dez annos para a prescripção da acção de reivindicação do navio, sem que se lhe possa oppôr falta de titulo ou de bôa fé, esclarecendo que quem possue um navio, por força de um titulo estipulado em bôa fé, devidamente registrado e que não seja nullo por defeito de fórma, conta em seu beneficio com a prescripção, pelo

(38) Sergio Loreto Filho, O commercio maritimo no direito internacional privado, pag. 86, n.' 24; Alfredo Russel, Curso de Dir. Com. Bras., III, 104.

(39) Lyon Caen et Renault, Traité de Droit Commercial, vol. 5, pag. 130; Georges RipPert, Droit Maritime, vol. 1, pag. 269, n. 310. 
decurso de cinco annos da data do titulo e da sua annotação no registro. 0 do Mexico, art. 642, preceitua que a posse do navio, sem titulo de sua acquisição, não attribue ao possuidor a sua propriedade, senão depois de dez annos continuos. $O$ do Chile, art. 828, permitte a prescripção no mesmo prazo, mas requer titulo e bôa fé, e no de trinta annos, faltando o titulo. $\mathrm{O}$ da Republica Argentina, art. 867 , contenta-se com o prazo de cinco annos, com justo titulo e bôa fé, mas, com falta de titulo, exige o prazo de vinte annos. O de Espanha, art. 573, fixa em dez annos o prazo da prescripção, mas o reduz a tres annos, se o possuidor tiver justo titulo e bôa fé.

o codigo portuguez, entretanto, no art. 487, consignou o principio de que "a posse do navio sem titulo de acquisição não importa propriedade" Não admitte a prescripção sem posse titulada.

E assim dispoz, como observa Cunha Gonçalves, "talvez no intuito de não estimular os corsarios; pois este art. 487 teve por fonte os arts. 1892 do codigo de 1883 e 7 do Acto de Navegação de 1863, épocas em que nenhum preceito legal prohibia em absoluto o corso" Deixou certo, entretanto, que a prescripção poderá operar-se em caso de posse titulada e de bôa fé, como se o documento de acquisição tiver sido feito com omissão de alguma formalidade legal e o titulo não tiver sido annullado por acção ou por excepção. E accrescentou que, "posto que o navio seja em alguns pontos equiparado aos immoveis, elle é uma coisa movel para o effeito da prescripção. Porisso, bastará a posse de tres annos, nos termos do art. 532 do codigo civil, mas a contar do registro da acquisição, pois só assim esta produzirá effeitos em relação a terceiros" (40).

(40) Luiz da Cunha Gonçalves, Commentarios ao Codigo Commercial Portuguez, vol. 3, pag. 97, n.' 730 .

Antigamente, em Portugal, "havia o chamado direito de naufragio, pelo qual se podiam apprehender livremente os objectos naufragados. E para acabar com tão espoliativo e barbaro uso, as legislações commerciaes começaram a consignar este principio de que 
O codigo brasileiro, porém, como o francez, não disse palavra sobre o assumpto. Silenciou. A prescripção acquisitiva da propriedade do navio, como bem movel, entretanto, não póde deixar de ser regulada pelo codigo civil, disciplinador dos direitos e obrigações de ordem privada concernentes ás pessôas, aos bens e ás suas relações, applicando-se-lhe as nórmas da acquisição e da perda da propriedade pelo usocapião.

II - O capitão de navio, terminantemente dispõe o art. 451 do codigo do commercio, não póde adquirir por titulo de prescripção a posse do em que servir, nem de cousa a elle pertencente.

37 - O ABANDONO LIBERATORIO - Quem se obriga, eis um principio universal de direito, obriga o que é seu: os bens do devedor constituem um penhor commum em favor dos seus credores. Soffre uma excepção, todavia, em direito maritimo, que o codigo do commercio poz no art. 494:

"Todos os proprietarios e compartes são solidariamente responsaveis pelas dividas que o capitão contrair para concertar, habilitar e aprovisionar o navio, sem que essa responsabilidade possa ser illidida, allegando-se que o capitão excedeu os limites das suas faculdade ou instrucções, se os credores provarem que a quantia pedida foi empregada a beneficio do navio. Os mesmos proprietarios e compartes são solidariamente responsaveis pelos prejuizos que o capitão causar a terceiro por falta de diligencia, que é obrigado a empregar, para a bôa guarda, acondicionamento e conservação dos effeitos recebidos a bordo. Esta responsabilidade cessa fazendo aquelles abandono do navio e fretes

não basta a occupação ou a simples posse para legalizar a propriedade de qualquer navio, e, portanto, de qualquer parte delle. Assim, para que haja prescripção é mister que haja um titulo. E, nesse caso, a prescripção applicavel é a do art. 532 do codigo civil". (Adriano Anthero, Commentario ao Codigo Commercial Portuguez, vol. 2, pag. 310). 
vencidos e a vencer na respectiva viagem. Não é permittido o abandono ao proprietario ou comparte que fôr, ao mesmo tempo, capitão do navio.

As mesmas dividas, sendo contraidas fóra do paiz, só serão attendidas, achando-se authenticadas com o visto do respectivo consul".

Cessa, como se vê, a responsabilidade solidaria dos proprietarios e compartes, pelas dividas contraidas pelo capitão para concertos do navio, ou pelos prejuizos causados á carga, cessa pelo abandono do navio e fretes vencidos e a vencer.

E' uma como que dação em pagamento, datio in solutum: quitação das dividas, mediante a entrega do navio e fretes aos credores.

Velho instituto do direito maritimo, adoptado pela Ordenança de 1681, tem sido justificado não sómente como medida incentivadora da industria da navegação, senão ainda pelo argumento de que sendo os proprietarios de navio obrigados a escolher o capitão num circulo muito limitado de pessôas, que reunam os requisitos estabelecidos pela lei e dotados, pela sua investidura, de tão largos poderes, ser-lhes-ia difficil fiscalizar-lhes os actos. Outros vêem nelle a applicação do principio da separação da fortuna do mar da fortuna de terra.

O navio e os fretes são abandonados aos credores, em seu proveito. E' um acto unilateral, dependente da resolução dos proprietarios do navio. Posto não tenham os credores direito real de garantia sobre o navio, pelo abandono cessa a responsabilidade daquelles e se outros navios tiverem, livres ficarão da acção dos credores pelas dividas contraidas pelo capitão do navio abandonado.

Chama-se abandono liberatorio porque, por via delie, os proprietarios e compartes do navio se liberam das dividas contraidas pelo capitão, durante a viagem, para o seu concerto e das obrigações oriundas da sua negligencia na conservação da carga. 
Tal instituto foi transplantado para o direito commercial terrestre, como uma das fórmas de concordata: a concordata por abandono, que a lei franceza de 17 de julho de 1856 incorporou ao systema fallimentar e que o projecto Nabuco de Araujo procurou introduzir no nosso direito, vindo a ser adoptada pelo decreto legislativo n. 3.065, de 6 de maio de 1882, e pelo decr. n. 917, de 24 de outubro de 1890 , art. 43.

Importava a concordata por abandono na adjudicação de todos os bens da massa, ou de parte delles, aos credores, para a solução do passivo, e em plena exoneração do devedor: um abandono liberatorio, com os mesmos effeitos e com o mesmo feitio do de direito maritimo.

Como, a respeito da concordata por abandono se manifestou J. X. Carvalho de Mendonça, no sentido de ser ella não uma concordata por pagamento, nem, propriamente, uma cessão de bens, formando-se, apenas, entre os credores um contracto de união para liquidar os bens abandonados e distribuir o producto entre si; a proposito do abandono liberatorio se exprimiu Albert Wahl, no sentido de ser elle não propriamente, um modo de acquisição de propriedade do navio, visto não importar na sua transferencia. Os credores reunir-se-ão para vender o navio e receber os fretes, entre si partilhando o producto. Reconhece, todavia, que a controversia não foi resolvida nem pela doutrina, nem pelos tribunaes francezes (41).

38 - O ABANDONO SUBROGATORIO - O abandono subrogatorio é o regulado pelo art. 753 do codigo commercial, que permitte ao segurado fazer abandono dos objectos seguros e pedir ao segurador a indemnização de perda total, nos seguintes casos:

(41) J. X. Carvalho de Mendonça, Das fallencias e dos meios preventivos de sua declaração, vol. 1, pag. 316, n. ${ }^{\circ} 504$; Albert Wahl, Précis Theorique et Pratique de Droit Maritime, pag. 447, n.' 1.075 . 
a) de presa ou arresto, por ordens de potencia estrangeira, seis mezes depois de sua intimação, se o arresto durar por mais deste tempo;

b) de naufragio, varação ou outro qualquer sinistro de mar comprehendido na apolice, de que resulte não poder o navio navegar, ou cujo concerto importe em tres quartos ou mais do valor por que foi segurado;

c) de perda total do objecto seguro, ou deterioração que importe pelo menos tres quartos do valor da cousa segurada;

d) de falta de noticia do navio sobre que se fez o seguro, ou em que se embarcaram os effeitos seguros.

Se, dispõe o art. 720 do codigo do commercio, passado um anno, a datar da saida do navio nas viagens para qualquer porto da America, e dois annos para qualquer outro porto do mundo, e tendo expirado o tempo limitado na apolice, não houver noticia alguma do navio, presume-se este perdido e o segurado pode fazer abandono ao segurador e exigir o pagamento da apolice: o qual, todavia, será obrigado a restituir, se o navio se não houver perdido ou se vier a provar que o sinistro aconteceu depois de ter expirado o termo dos riscos.

Em qualquer desses casos, aos proprietarios do navio é licito abandonal-o á companhia seguradora, operando-selhe a transferencia de sua propriedade, afim de pedir-lhe a indemnização total do seguro.

A expressão abandono, de que o codigo se serve, não deve ser confundida com a da giria maritima para referir-se ao navio desamparado pela sua tripulação, receiando o seu naufragio. O abandono, aqui, é a entrega do navio á companhia seguradora.

Chamou-o Silva Costa de abandono subrogatorio no intuito de distinguil-o do abandono liberatorio (42).

(42) José da Silva Costa, Direito Commercial Maritimo, vo.. 2 , pag. 291, n. $^{\circ} 812$. 
$\mathrm{E}$ isso porque "elle é uma verdadeira subrogação pessoal latu senso, consistente na substituição juridica de uma pessôa por outra, em vista de permittir á primeira o exercicio, no proprio interesse pessoal, de todos ou da parte dos direitos que pertencem á segunda: é a noção de BAUdry-LACANTINerie. Não é diverso o conceito do art. 728 do codigo do commercio, quando declara o segurador subrogado nos direitos e acções do segurado, desde que a este paga o damno acontecido. Abandonando ao segurador o objecto do seguro, nos casos em que lhe é licito fazel-o, o segurado nada mais faz do que collocar o segurador na posição juridica em que elle se acha, no momento do abandono"

\section{A PARCERIA MARITIMA}

39 - A EXPLORAÇÃO INDUSTRIAL DO NAVIO -Todos os cidadãos brasileiros, com excepção dos corretores e leiloeiros, podem adquirir e possuir navio brasileiro: eis o principio pelo codigo de commercio posto no seu art. 484 e pelo decr. n. 17.096, de 28 de outubro de 1925, desenvolvido no seu art. 395; mas, accentuaram ambas as leis, a sua armação e expedição só podem girar sob o nome e responsabilidade de um proprietario ou comparte, armador ou caixa, que tenha as qualidades necessarias para ser commerciante.

Para os fins industriaes, não basta possuir o navio e ter-lhe a propriedade. E' essencial armal-o e expedil-o. $O$ proprietario é o dono. $O$ armador, o seu explorador, aquelle a quem tocam todos os proventos e que lhe supporta os onus, da exploração oriundos.

Póde o navio, portanto, pertencer a um ou mais cidadãos brasileiros, singular ou collectivamente.

40 - A EXPLORAÇÃO SOB FIRMA INDIVIDUAL --Quando um só é o dono do navio, como legitimo senhor e 
possuidor, elle o explorará, se quizer, por sua conta e risco, tirando as vantagens e arcando com os onus do emprehendimento.

O caso é simples e, no que concerne á propriedade e ao exercicio dos direitos della decorrentes, não offerece grandes difficuldades. Unidade de direcção. Unidade de acção. Responsabilidade individual do proprietario pelos actos, que praticar, e pelos contractos, que celebrar.

41 - A COMPROPRIEDADE DO NAVIO - Quando mais de uma pessôa possuir o mesmo navio, póde elle ser objecto de uma simples communhão, de uma compropriedade, de uma parceria maritima, ou de uma sociedade commercial.

A propriedade collectiva póde resultar de um facto, de um contracto de fórma especial, ou de uma sociedade mercantil: ou os proprietarios possuem o navio em commum, sem organização de sociedade, regularmente constituida e registrada, mercê de uma verdadeira communhão, condominio ou compropriedade; ou de uma parceria maritima, sociedade de feitio todo especial, regida pelas disposições, que lhe são peculiares, do codigo do commercio; ou de uma sociedade mercantil, organizada de accôrdo com os preceitos legaes, caso em que, mercê da personalidade juridica das sociedades commerciaes, se tratará, mais apropriadamente, de uma propriedade singular.

Dá-se a communhão, condominio, ou compropriedade, quando duas ou mais pessôas, sem intuito de sociedade, possuem um navio mercante, ou por herança, ou por adjudicação, ou por doação; ou, mesmo, por compra. Em regra, surge a communhão independentemente da vontade dos communheiros. Posto que, como observa Giovanni LoMonaco, "posto que, de ordinario, surja a communhão sem convenção, não se póde dizer que tal seja o caracteristico differencial entre a sociedade e a communhão: que a sociedade suppõe, sempre, uma convenção, e que a communhão, ao contrario, a exclue. Adoptando este criterio, de- 
ver-se-ia admittir a existencia de sociedade em todos os casos em que, por força de uma convenção, se encontrasse uma coisa commum a muitas pessôas. Contra isso, todavia, se rebellaria o bom senso. Offerecem-se, por exemplo, á venda, duas partes indivisas de um mesmo predio. Duas pessôas, separadamente, as compram. Que resulta dahi? Uma sociedade ou uma communhão? Certamente, uma communhão. Ensina-o o jurisconsulto Paulo: Ut sit pro socio actio, societatem intercedere oportet; nec enim sufficit rem esse communem, nisi societas intercedit. Communiter autem res agi potest etiam citra societatem cum non affectione societatis incidimus in communionem, ut evenit in res duobus legata; item simul res empta sit; ait si a duobus separatim emimus partes corum, non socii futuri (L. 31, D., pro socio). Logo, como dissemos, casos existem nos quaes a convenção dá origem á communhão, não á sociedade. Para existir sociedade é necessario aquillo que Ulpiano, no fragmento citado, chama affectio societatis, a intenção de reunir em um só feixe diversos capitaes, diversas forças individuaes, para obter desta somma de capitaes e de forças as vantagens que aos socios, isoladamente, não seria possivel obter" (43).

Seja, como bem synthetizou Clovis Bevilaqua, "seja, porém, a communhão convencional ou contractual, seja incidente ou eventual, differe da sociedade, apesar de haver numa e noutra bens communs. Falta na communhão a affectio societatis, que se traduz pela cooperação, pelo sentimento, que tem o socio de que, trabalhando para a sociedade, trabalha no seu proprio interesse, e, promovendo o seu interesse dentro da sociedade, influe no desenvolvimento das vantagens, que os outros socios visaram, associando-se" (44).

(43) Grovanni Lomonaco, Istituzioni di Diritto Civile Italiano. vol. 3 , pag. 483 .

(44) Clovis Bevilaqua, no Manual do Codigo Civil Brasileiro, vol. 14, pag. 11, n.' 8 . 
Na propriedade em commum, compropriedade, ou condominio, segundo a regra de direito consignada no art. 623 do codigo civil, cada condomino ou consorte póde usar livremente da coisa, conforme seu destino, e sobre ella exercer todos os direitos compativeis com a indivisão; reivindical-a de terceiro; ou alhear a respectiva parte indivisa, ou graval-a.

Como é de ver, tal regimen, applicado á compropriedade do navio, traria tantos empecilhos á sua exploração industrial e commercial, que esta se tornaria, senão impossivel, por certo difficilima e, numa ou noutra hypothese, improficua. Elaborando um codigo, que, no dizer de DesJARDINS, póde reputar-se excellente, como expoente da sciencia e da pratica commercial do tempo de sua promulgação (45), não podia o legislador brasileiro ter deixado de regular a materia.

Disciplinou-a.

42 - A PARCERIA MARITIMA - Quando, refere o art. 485 do codigo de commercio, os compartes de um navio fazem delle uso commum, esta sociedade ou parceria maritima regula-se pelas disposições das sociedades commerciaes, salvas as determinações especiaes contidas no titulo segundo da parte segunda do codigo commercial.

Não se conclua dahi, como adverte Albert Wahl, que a compropriedade ou indivisão do direito civil seja incompativel com o direito maritimo: quando o navio faz objecto de uma successão indivisa, ou foi adquirido mercê de uma venda a diversas pessôas, ou lhes foi doado, e não haja vontade destes de associarem-se, a compropriedade é regida pelas regras do direito civil (46). Desde que, porém, os compartes se resolvam a fazer delle "uso commum", a compropriedade se transformará numa sociedade, de feitio todo

(45) DesjaRdins, Introduction historique, pag. 432.

(46) Albert Wahl, Précis Théorique et Pratique de Droit Maritime, pag. 49 , n.' 73. 
especial e muito antiga. Das expressões do codigo deduziu Brasilio Rodrigues dos Santos que, dada uma communhão ou compropriedade, que tenha por objecto o navio, desde que os communheiros ou comproprietarios façam delle uso commum, tanto basta para que se verifique a existencia da sociedade denominada parceria maritima. Mas reparou que "este conceito do legislador brasileiro é absolutamente injustificavel, porquanto é fóra de duvida que diversos communheiros podem fazer uso commum do navio de sua compropriedade, sem que disso resulte entre os condominos a existencia duma sociedade ou parceria maritima. $O$ uso commum pode se fazer, por exemplo, para uma expedição scientifica de qualquer ordem, para outros fins completamente extranhos ás relações commerciaes" E concluiu que "os caracteristicos ministrados pelo legislador patrio no codigo são absolutamente insufficientes para distinguir a parceria maritima da communhão" (47).

A verdade é, entretanto, que, pela exploração, no exprimir-se de Albert Wahl, ou pelo uso commum, no sentido do texto, a parceria maritima se distingue da compropriedade. Desde que os compartes se resolvem a explorar o navio, delle fazendo uso commum, forma-se, no entender de Ferreira Borges, "uma como sociedade necessaria" (48); pois, como explica Cunha Gonçalves, a parceria "é o estado de communhão em que os comproprietarios, fazendo uso commum do navio, exercem a navegação, seja directamente, seja por intermedio de um armador gerente. A especulação maritima é feita sem animo de sociedade: é a parceria em consequencia de objecto indivisivel a que se referem os arts. 577 e 579 do codigo de 1883" (49).

(47) Brasilio dos Santos, Lições de Direito Maritimo, stenographadas por Antonio Toledo, pag. 73.

(48) José Ferreira Borges, Diccionario Juridico-Commercial, pag. 352.

(49) Luiz da Cunha Gonçalves, Commentario ao Codigo Commercial Portuguez, vol. 3, pag. 157, n. 769. 
De sorte que, como observa Silva Costa, "o facto de haver compartes e quererem estes fazer do navio uso commum, importa a existencia de uma parceria maritima" (50).

(50) José da Silva Costa, Direito Commercial Maritimo, vol. 1, pag. $168, \mathrm{n} .^{\circ} 152$.

- Suggestivo, e por isso mesmo digno de relevo, o capitulo que, a proposito, traçou Teixeira de Freitas nos Additamentos ao Codigo do Commercio, 2 vol., pag. 937:

"Os compartes (OrL. Com. not. 716, pag. 190) de um navio formam uma sociedade ou parceria maritima? Não. As palavras: uso commum excluem a duvida. A copropriedade constitue apenas uma simples communhão de interesses."

E' procedente a solução da proposta duvida no sentido da communhão não ser sociedade, mas não segundo a nomenclatura do art. 485.

Se o art. 485 diz: esta sociedade ou parceria maritima, bem se vê que tambem reputa sociedade ou parceria maritima a communhão ém navio, quando os compartes não fazem delle uso commum.

Para o art. 485, pois, são compartes de navio não só os que nelle tèm sociedade (quando delle fazem uso commum), como os que nelle tèm simplesmente communhão; mandando na primeira hypothese applicar as disposições sobre o contracto de sociedade, desde o art. 287 ao art. 353 , salvas as determinações especiaes sobre o assumpto das sociedades maritimas.

Tal nomenclatura não causa extranheza, porque não poucos escriptores usam da expressão sociedade em sentido generico, distinguem-n'a em sociedade tacita e sociedade expressa, e na primeira especie collocam a communhão.

“E' impossivel (Consolid. das Leis Civis, not. 1 ao art. 742, pag. 458) estar em sociedade, sem que se esteja em communhão; mas pódeso estar em communhão sem estar em sociedade. Assim costumam dizer os escriptores, mas se, constituida a sociedade, ha uma pessoa moral distincta dos socios, que a compõem; e tendo, portanto, seu patrimonio, que vem a ser a totalidade das entradas sociaes consistentes em bens; como conceber esse patrimonio, suppondo-se ao mesmo tempo que os socios estejam em communhão de bens?"

A explicação vem a ser que ha dois aspectos nas sociedades; o generico, quando se considera a unidade do patrimonio social; o especifico, quando se attende á pluralidade dos quinhões dos compartes. 


\section{3 - A CONSTITUIÇÃO DA PARCERIA MARITIMA} - Constitue-se a parceria maritima, portanto, sem contracto escripto e assim tem acontecido desde os tempos mais remotos, como annota Albert WaHL, mercê da hostilidade dos navegantes pelos documentos escriptos. Ella emerge da compropriedade, seja qual fôr o motivo determinante

De resto, nas apontadas palavras do Com. de Orlando, not. 716, pag. 190: uma simples communhão de interesses, tomou-se a parte pelo todo, como se toda a communhão fosse de interesses.

Quando (eis a doutrina já supra estampada ao art. 303, pag. 675) não exista sociedade legitimamente constituida, ou contractada emı fórma legal, existiu todavia uma sociedade de facto, uma communhão de bens ou communhão de interesses, etc.

Se o art. 485 diz: esta sociedade ou parceria maritima, bem se vè egualmente, que reputa sociedade a parceria maritima; e portanto não seguiu as confusas distincções de Ferreira Borges, em seu Contracto de Sociedade, reproduzidas no seu Diccionario Commercial, assim :

"Parceria (Contr. de Socied., § 39) é uma associação, mas não uma sociedade. Os parceiros são compartes ou co-interessados, mas não são socios. Parceiro é o que tem quinhão junto",

"O uso tem muitas vezes confundido o nome parceria ou parçaria, como antes disseram, com sociedade. A mesma Ord., L. 3, I $59, \S 13$, parece tomal-a por synonimo de sociedade, emquanto que a do L. 4, T. 45 a estrema devidamente, etc."

Entretanto, estas duas Ords. parecem concordes, na da L. 4, T 45, § 2, leio: contracto de parceria; e por isso na Consol. das Leis Civis, not. 4 ao art. 653, pag. 457, considerei o arrendamento de parceria um caso de contracto de sociedade, e não de communhão.

"Parceria (Dir. Com.) não é sociedade (que confusão!) é uma participação em commum, não é uma communhão mixta, é um senhorio pro indiviso, relativo, não absoluto! Cumpre ter bem em vista estas differenças, porque, confundindo-se esta associação como uma sociedade, os resultados juridicos podem ser absurdos. Este nome, rio sentido commercial maritimo, cabe precipuamente á associação que existe entre os diversos proprietarios de um só navio"

Ao contrario, na palavra associação acham todos um contracto, ou resultado delle; e, tendo havido contracto, ha sociedade, e não communhão no sentido especifico.

Parece haver nesta palavra - parceria, um mysterio, que a doutrina de hoje não quer, ou não póde, perceber ou explicar!" 
desta, desde que os compartes façam uso commum do navio, ou o explorem em beneficio commum. Simples communhão de interesses, no pensar de alguns; compropriedade organizada, no de outros - sociedade ella é, por força de lei. Sociedade em conta de participação, em face da lei belga de 10 de fevereiro de 1908, que o codigo de commercio allemão regula, nos arts. 499 a 510 como sociedade por acções: roederei (ou mascopei) - tem ella, como os escriptores francezes salientam, feitio proprio, que a extrema das demais sociedades mercantis. Não tem firma ou razão social. Nem denominação, senão o nome do proprio navio. Posto solidarios, ha momentos em que se limita a responsabilidade dos compartes, que podem transferir os seus quinhões, affrontando aos outros compartes. Não é sociedade em nome collectivo. Nem em commandita. Nem anonyma. E' uma sociedade sui generis.

Embora creada pela lei, e por ella regulada, careoe de personalidade juridica. Começa, nos termos do art. 18 do codigo civil, a existencia legal das pessôas juridicas de direito privado com a inscripção dos seus contractos, actos constitutivos, estatutos ou compromissos no seu registro peculiar, regulado por lei especial, ou com a autorisação ou approvação do governo, quando precisa.

E a parceria maritima independe de acto escripto. Pode, no emtanto, constituir-se por instrumento particular, ou publico. Neste caso, da inscripção ou registro deste lhe resultará a personalidade juridica.

A parceria maritima, crê Juan Carlomagno, com Ripert, como todas as sociedades commerciaes, tem personalidade juridica. O socio pode dispôr de sua parte como o accionista de sua acção. A sociedade, na maior parte das vezes, é representada por uma unica pessôa - o armador, que representa a todos os associados e age em nome delles, judicial ou extrajudicialmente, investido dos poderes outorgados pelo codigo ou pela estipulação dos socios. Se tal 
conclusão é legitima, em face do codigo argentino (51), ou do francez, não o é deante do brasileiro (52).

Pois não está expresso no art. 18 do codigo civil que a existencia legal das pessôas juridicas de direito privado começa com o archivamente, no seu registro peculiar, do acto de sua constituição? Pois não está declarado no art. 491 do codigo do commercio que o caixa, se administra a sociedade de navio, "representa em juizo e fóra delle a todos os interessados, e os responsabiliza"? Porque só a estes representa e não á sociedade? Pois não permitte o art. 489 que "se algum comparte na embarcação quizer vender o seu quinhão", primeiro affronte os outros parceiros?

Se isso é assim, é porque, evidentemente, a parceria carece de personalidade juridica: o navio continua a pertencer aos compartes. Não entra para o patrimonio social, mesmo porque este não existe.

44 - A ADMINISTRAÇÃO DA PARCERIA MARITIMA - A parceria é administrada por um caixa. Um ou mais caixas. Compete a nomeação aos compartes, de entre elles. Mas pode, convindo todos, recair em extranho. Deve o nomeado ser cidadão brasileiro e reunir as qualidades necessarias para ser commerciante.

Como gerente da parceria, salvo convenção em contrario, pode o caixa:

a) nomear, ajustar e despedir o capitão e mais officiaes do navio;

b) dar ordens e fazer contractos relativos á administração, fretamento e viagens do navio.

Agirá, sempre, em conformidade com as deliberações da maioria e nos termos do seu mandato, sob sua responsabilidade pessoal, para com as partes, pelos actos que pra-

(51) Juan C. Carlomagno, Manual de Derecho Maritimo, pag. 143, n. $^{\circ} 532$.

(52) Waldemar Ferreira, Sociedades Commerciaes Irregulares, pags. 64 e 108 e seguintes. 
ticar contra o deliberado ou contra ou além dos seus poderes. Prestará contas de sua gestâo, ao fim de cada viagem, tanto relativas ao estado do navio e da parceria, como da viagem finda, acompanhadas dos documentos competentes. E pagará, sem demora, o saldo que couber a cada comparte, podendo de cada um exigir as quotas, na proporção de seu quinhão, necessarias para a cobertura das despezas.

Não obsta, esclarece o art. 495, a approvação das contas pela maioria dos socios a que a minoria intente as acções, que julgar convenientes, ou para impugnal-as total ou parcialmente, ou para revel-as e acertal-as.

45 - AS DELIBERAÇõES DOS PARCEIROS - Na parceria, preceitua o art. 486, o parecer da maioria no valor dos interesses prevalece contra o da minoria nos mesmos interesses, ainda que esta seja representada pelo maior numero de socios e aquella por um só.

Computam-se os votos na proporção dos quinhões; o menor quinhão será contado por um voto: no caso de empate decidirá a sorte, se os socios não preferirem commetter a decisão a um terceiro, devendo, neste caso, ser observadas as prescripções dos arts. 1.037 e seguintes do codigo civil, sobre o compromisso.

E' de não esquecer, todavia, e no art. 331 do codigo do commercio ficou patente, que a maioria dos socios não tem faculdade de entrar em operações diversas das convencionadas no contracto, ou da natureza da sociedade, sem o consentimento unanime de todos os socios.

Se, acaso, necessitar o navio de concerto e neste convier a maioria, os socios dissidentes, se não quizerem annuir, serão obrigados a vender os seus quinhões aos outros compartes, estimando-se o preço antes de começar o concerto; e se estes não os quizerem comprar, proceder-se-á á venda em hasta publica. Não deixou o art. 487 desamparada a minoria: resguardou-lhe o interesse. Identico principio se encontra no art. 15 do decr. n. 3.708, de 10 de ja- 
neiro de 1919, mercê do qual assiste aos socios, que divergirem da alteração do contracto da sociedade por quotas, de responsabilidade limitada, a faculdade de retirarem-se della, obtendo o reembolso da quantia correspondente ao seu capital, na proporção do ultimo balanço approvado.

Entendendo a minoria dos compartes, entretanto, que o navio necessita de concerto, assiste-lhe, e o art. 488 lhe concede, se a maioria se oppuzer, o direito de requerer vistoria judicial: decidindo-se, nesta, que o concerto é necessario, são todos os compartes obrigados a contribuir para elle.

Se algum comparte quizer vender o seu quinhão no navio, será obrigado a affrontar os outros parceiros, offerecendo-lhes, pois elles têm direito a preferir na compra, em egualdade de condições, comtanto que effectuem a entrega do preço á vista, ou o consignem em juizo, no caso de contestação (53).

Resolvendo-se a venda do navio, por deliberação da maioria, cabe á minoria o direito de exigir que seja feita em hasta publica.

Além desse direito de preferencia para acquisição dos quinhões dos compartes, confere-lhes o art. 490 o de preferir, no fretamento, a qualquer terceiro, em egualdade de condições: concorrendo, na preferencia, para a mesma viagem, dois ou mais compartes, caberá ao que tiver maior interesse na embarcação, decidindo a sorte, no caso de egualdade. A preferencia, todavia, não dá direito para exigir que se varie ao destino da viagem accordada pela maioria.

(53) O direito dos compartes no navio preferirem tanto por tanto na venda do quinhão de cada um, tinha, outr'ora, o nome de retracto parciario (TeIXeIRa DE Freitas, Additamentos ao Codigo do Commercio, 2. vol., pag. 941, nota ao art. 489; Visconde DE Cíayú, Principios de Direito Mercantil e Leis de Marinha, vol. 2, pag. 647). 
46 - A RESPONSABILIDADE DOS PARCEIROS Sendo o caixa de nomeação dos compartes, respondem estes pelos seus actos, nos limites do contracto social e do mandato que lhe houverem outorgado.

Respondem, ademais, pelos actos do capitão do navio e pelos prejuizos que causar a terceiros, por falta de diligencia.

Tal é da essencia da representação e dois são os agentes dos compartes: o caixa e o capitão, dirigindo este o navio e administrando aquelle a parceria.

47 - A ASSOCIAÇÃO DA EQUIPAGEM AOS PARCEIROS - Afora a parceria entre os compartes do navio, pode ella ser constituida quer entre os comproprietarios e a equipagem, percebendo estes, em vez de soldadas, lucros ou partes nos fretes e ganhos do navio: navegação a partes $e$ quinhões no frete, do art. 553; quer entre os comproprietarios, equipagem e os carregadores.

DR. WALDEMAR FERREIRA

(Professor cathedratico de Direito Commercial) 